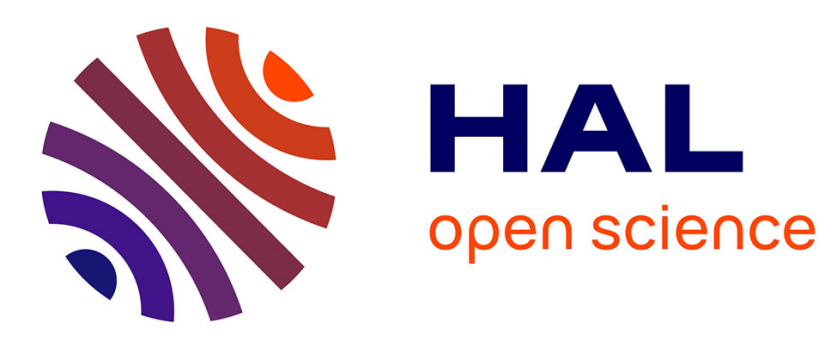

\title{
Effects of Genistein and Estrogen Receptor Subtype-Specific Agonists in ArKO Mice Following Different Administration Routes
}

Anja Bliedtner, Oliver Zierau, Steffen Albrecht, Stefanie Liebhaber, Günter Vollmer

\section{To cite this version:}

Anja Bliedtner, Oliver Zierau, Steffen Albrecht, Stefanie Liebhaber, Günter Vollmer. Effects of Genistein and Estrogen Receptor Subtype-Specific Agonists in ArKO Mice Following Different Administration Routes. Molecular and Cellular Endocrinology, 2009, 314 (1), pp.41. 10.1016/j.mce.2009.07.032 . hal-00529006

\section{HAL Id: hal-00529006 https://hal.science/hal-00529006}

Submitted on 24 Oct 2010

HAL is a multi-disciplinary open access archive for the deposit and dissemination of scientific research documents, whether they are published or not. The documents may come from teaching and research institutions in France or abroad, or from public or private research centers.
L'archive ouverte pluridisciplinaire HAL, est destinée au dépôt et à la diffusion de documents scientifiques de niveau recherche, publiés ou non, émanant des établissements d'enseignement et de recherche français ou étrangers, des laboratoires publics ou privés. 


\section{Accepted Manuscript}

Title: Effects of Genistein and Estrogen Receptor

Subtype-Specific Agonists in ArKO Mice Following Different

Administration Routes

Authors: Anja Bliedtner, Oliver Zierau, Steffen Albrecht,

Stefanie Liebhaber, Günter Vollmer

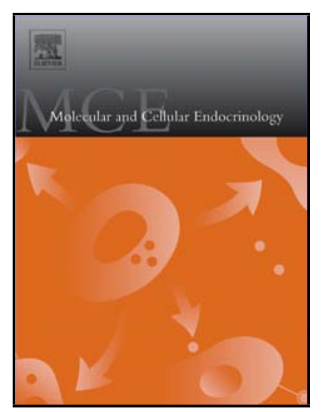

PII:

S0303-7207(09)00404-3

DOI:

doi:10.1016/j.mce.2009.07.032

Reference:

MCE 7281

To appear in: $\quad$ Molecular and Cellular Endocrinology

Received date: $\quad$ 13-2-2009

Revised date: $\quad$ 9-7-2009

Accepted date: $\quad 31-7-2009$

Please cite this article as: Bliedtner, A., Zierau, O., Albrecht, S., Liebhaber, S., Vollmer, G., Effects of Genistein and Estrogen Receptor Subtype-Specific Agonists in ArKO Mice Following Different Administration Routes, Molecular and Cellular Endocrinology (2008), doi:10.1016/j.mce.2009.07.032

This is a PDF file of an unedited manuscript that has been accepted for publication. As a service to our customers we are providing this early version of the manuscript. The manuscript will undergo copyediting, typesetting, and review of the resulting proof before it is published in its final form. Please note that during the production process errors may be discovered which could affect the content, and all legal disclaimers that apply to the journal pertain. 
1 Effects of Genistein and Estrogen Receptor Subtype-Specific

2 Agonists in ArKO Mice Following Different Administration Routes

3 Anja Bliedtner ${ }^{* 1}$, Oliver Zierau ${ }^{1}$, Steffen Albrecht ${ }^{2}$, Stefanie Liebhaber ${ }^{1}$, Günter

4 Vollmer $^{1}$

5

6

$7 \quad{ }^{1}$ Chair of Molecular Cell Physiology and Endocrinology, Institute for Zoology, Technische

8 Universität Dresden, Germany

$9 \quad{ }^{2}$ Department of Gynaecology and Obstetrics, University Hospital Carl-Gustav-Carus

10 Technische Universität Dresden, Germany

11

12

13

DISCLOSURE STATEMENT: The authors have nothing to disclose.

* Corresponding author:

17

18

Anja Bliedtner

19

20

Technische Universität Dresden

Institut für Zoologie

21

Zellescher Weg 20b, Raum 249,

22

23

01217 Dresden

Germany

Phone: +49 35146334733

Fax: +4935146331923

Email: anja.bliedtner@tu-dresden.de

26

27

28 
Keywords: ArKO mice, estrogen receptors, ER-subtype-selective ligands, uterotrophic assay, genistein

\section{Abstract}

We have scrutinized the effects of the phytoestrogen genistein and three synthetic estrogen receptor agonists, $17 \alpha$-ethynylestradiol (EE), propylpyrazole-triol (PPT) and diarylpropionitrile (DPN) in the completely estrogen-free background of aromatase knockout (ArKO) mice by means of two routes of substance administration: oral via diet (per os; po) or subcutaneous injection (sc) with the intention to evaluate the ArKO mice as sensitive model organism for uterotrophic assays. Additionally, we were aiming to qualitatively analyze effects resulting from oral administration path, in particular for PPT and DPN. Therefore, we analyzed the resulting uterine wet weights (UWW) and epithelial heights as physiological endpoints of function as well as the gonadotropin levels. Moreover, the gene expression profiles of estrogen receptors as well as important uterine and ovarian estrogen-response genes were investigated by real-time PCR.

The uterus of ArKO mice responded very sensitive upon the substitution with EE (sc $5 \mu \mathrm{g} / \mathrm{kg} \mathrm{BW}$; po $50 \mu \mathrm{g} / \mathrm{kg} \mathrm{BW}$ ) in a proliferative manner. This was evaluated inter alia by increased UWW and by up-regulation of the expression of proliferationassociated and estrogen-response genes. It is important to note, that ER $\alpha$ and ER $\beta$ agonist, PPT and DPN respectively (po $5 \mathrm{mg} / \mathrm{kg} \mathrm{BW}$ and sc $0.5 \mathrm{mg} / \mathrm{kg} \mathrm{BW}$ ), so far have only been just for sc applications. Here, effects resulting from oral application were qualitatively described evaluated for their applicability. The UWW and expression of proliferation-associated genes were increased following both po and SC treatment with PPT. DPN did not exert an increase of the UWW, but a significant decrease of proliferation-associated gene and protein expression. Additionally, a substantial hypoplasia was detectable in the uterine cross sections of DPN-treated mice. On the other hand, the phytoestrogen genistein (sc $10 \mathrm{mg} / \mathrm{kg} \mathrm{BW}$; po 70 $\mathrm{mg} / \mathrm{kg} \mathrm{BW}$ ) did not cause detectable uterotrophic responses or large changes of uterine and ovarian gene expression profiles under the applied experimental conditions, but significantly reduced the elevated gonadotropin levels of ArKO mice. In summary, we showed the utility of ArKO mice to detect ER-specific effects, in particular those of PPT and DPN also when applied orally. 
60

61

62

63

64

65

66

67

68

69

70

71

72

\section{Introduction}

Estrogens play an important role in development and maintenance of secondary sexual organs and in regulation of reproductive functions in the female organism. In particular, the uterine and the ovarian functions are tightly regulated and coordinated mainly by $17 \beta$-estradiol (E2) in liaison with progesterone. Female reproductive organs, such as the uterus, the ovaries and the mammary glands are primary estrogen target organs and therefore express high amounts of estrogen receptors (Pelletier and El-Alfy, 2000). The responsiveness of those organs upon estrogen treatment is utilized in so called uterotrophic assays and extensively studied in various in vitro and in vivo test systems mostly by evaluating the growth and the proliferation potential as well as determining alterations of gene expression (Diel et al., 2002).

Estrogenic effects are mediated through the two estrogen receptors (ERa and ER $\beta$ ) (Green et al., 1986, Greene et al., 1986, Kuiper et al., 1996, Mosselman et al., 1996). They are encoded by two separate genes (ESR1 and ESR2, respectively), but share the common structural architecture of nuclear receptors. These transcription factors exhibit an evolutionary conserved domain structure; reviewed by Heldring et al. (2007). In the central DNA-binding domain, both estrogen receptors share the highest sequence similarity (95\%), which allows them to bind to identical DNA response elements. Despite exhibiting merely 60\% similarity, the C-terminal ligandbinding domains bind E2 with equivalent affinities but also permit ER-subtype specificity for different ligands.

There exists a variety of natural and synthetic substances influencing ER signaling. On the one hand, the specificity of substances to only one ER-subtype is useful for a pharmacological evaluation of the contribution of either receptor to the observed response, and therefore may lead to new therapeutic potentials or strategies. On the other hand, the substances themselves can be characterized by their potentials for activation or inhibition of specific ER functions.

Both ERs differ in their tissue distribution throughout the organism and play distinct physiological roles. These complex functional properties can not be fully assessed even if different in vitro test systems are combined. Whereas, the rodent uterotrophic assay is a validated and extensively used test system for evaluating estrogenic potency of substances (Kanno et al., 2001, Saarinen et al., 2006). There exist different protocols for investigating estrogenic-responses in estrogen-low or -deprived 
animals, for instance immature females or adult ovariectomized rodents. Those are treated for three or more days with estrogenic compounds, followed by determination of total uterine weight and organ resection for tissue-specific gene expression analyses (Diel et al., 2002). According to Diel and Odum, the choice of rodent species does not seem to be a critical factor in this assay, since the sensitivity to various receptor ligands appears to be similar in rats and mice (Diel et al., 2002, Odum et al., 1997).

However, the aromatase knock-out (ArKO) mice may be useful alternatives to study estrogenic responses, because both ERs are still intact and functional (Simpson, 2004), while in difference to the ovariectomized rodent model the progestogens are not compromised. In addition, the ovariectomy is not necessary, because these animals are completely devoid of endogenous estrogen production due to their defective estrogen biosynthesis resulting from disruption of the aromatase gene (CYP19a) (Fisher et al., 1998). However, the responsiveness to exogenous estrogens account for ER-subtype specificity studies, such as analyzing hormonal potency of xeno- and phytoestrogens.

In the present study, we analyzed the effects in the uterus and the ovaries of four reference substances following oral or subcutaneous application, the phytoestrogen GEN and two synthetic ER-specific agonists (PPT and DPN) as well as EE and compared these to the carrier-control group. GEN is a mild-selective agonist for ER $\beta$ with more than 7-fold higher binding affinity for ER $\beta$ than ERa (Kuiper et al., 1997). PPT has a 410-fold binding preference for ERa over ERß (Stauffer et al., 2000). Accordingly, ER $\beta$ is almost not bound and therefore not activated. DPN represents, at least within a limited dosage range, agonistic properties for ER $\beta$ with more than 70-fold higher binding preference for ER $\beta$ than ERa (Meyers et al., 2001). EE is a well-known orally active steroidal derivative of the natural $17 \beta$-estradiol and an approved reference ER-agonist (Kanno et al., 2001, Rider, 2002).

The uterus and the ovaries were chosen as two estrogen-target organs with clear differences in ER-distribution. ERa is the predominant ER-subtype expressed in the uterus acting as the major regulator of estrogenic signaling. ERa activation induces cell proliferation and primes for progesterone action, therefore preparing for decidualization and implantation (Frasor et al., 2003). Furthermore, studies of the ERß-deficient mice demonstrate typical uterine ERa-effects, such as increasing wet weight, cell proliferation, water imbibition and hyperemia (Krege et al., 1998, Couse 
128 and Korach, 1999). The ER $\beta$ is minorly present in all uterine cell types (Weihua et al.,

129 2000). Accordingly, the functional properties of ER $\beta$ in the uterus are less obvious,

130 even though it provokes some estrogenic effects, for instance increasing

131 progesterone receptor $(\underline{P G R})$ expression (Kurita et al., 2001) and modulating ERa

132 actions (Weihua et al., 2000).

133 In female individuals, the ovaries are the main source of endogenous estrogen

134 production. In addition, estrogens control follicular development in the ovaries with

135 great importance for reproduction. These influences might be directly effected via

136 ERs, which are located in the somatic cells of the ovaries, or indirectly as

137 consequences of modulation of gonadotropin levels (Britt et al., 2004). Both ERs are

138 expressed in the ovary with ER $\beta$ being the predominant subtype. Upon activation,

$139 \mathrm{ER} \beta$ influences the proliferation and development of granulosa cells (Drummond et

140 al., 1999). However, the precise molecular mechanism of regulations is still

141 ambiguous.

142 In this study, we were interested in the potentiality of PPT and DPN together with

143 genistein following an oral application path in a totally estrogen-free animal model.

144 Therefore, we examined their effects in the ArKO mice in qualitative similarity to the

145 respective Sc groups and compared all with the EE groups and carrier-control.

146 Hence, we analyzed physiological parameters and additionally detailed molecular

147 mechanisms in the uterus and the ovaries on mRNA and protein level.

148 Materials and Methods

149 Substances

150 17a-ethynylestradiol (EE; 17a-ethynyl-1,3,5(10)-estriene-3,17 $\beta$-diol;19-Nor-1,3,5(10),

151 17a-pregnatrien-20yne-3,17-diol) and genistein (GEN; 4',5,7-trihydroxyisoflavone)

152 were purchased from Sigma-Aldrich (Deisenhofen, Germany), propylpyrazole-triol

153 (PPT; 4, 4',4" - (4 -propyl-(H)-pyrazole-1,3,5 -triyl) trisphenol) and diarylpropionitrile

154 (DPN; 2, 3-bis (4-hydroxyphenyl)-propionitrile) were purchased from Tocris

155 Bioscience (Bristol, UK).

156 Animals

157 The ArKO mice and wild-type (WT) littermates used in this study were bred from the

158 founder population kindly provided by Prof. Dr. Evan Simpson (Prince Henry's 159 Institute of Medical Research, Clayton, Australia). The mice were housed under 
160 controlled conditions of temperature $\left(20 \pm 1{ }^{\circ} \mathrm{C}\right.$, relative humidity $\left.50-70 \%\right)$ and

161 illumination ( $12 \mathrm{~h}$ light $/ 12 \mathrm{~h}$ dark) and had free access to diet and water. The

162 company Altromin (Lage, Germany) produced the standard and the experimental

163 diets containing the test substances. An isoflavone-free diet with a $17 \%$ protein-

164 content based on milk-protein was used as standard chow. All animal handling and

165 experimental conditions were conducted in accordance to the principles and

166 procedures of the German Federal Law for Animal Welfare and were approved by

167 the Animal Care and Use Committee of the Technische Universität Dresden.

168 Treatment and experimental design

169 The substances were administered either per os (po, orally) via diet or by 170 subcutaneous (sc) injection according to a three-day uterotrophic assay. The ArKO

171 mice of an average age of 8 weeks were randomly divided into experimental groups

172 and the control group (designated as CO) $(n=5-8)$. Moreover, a group of female

173 wild-type littermates $(\mathrm{WT} ; \mathrm{n}=6)$ with the same genetic background $(\underline{\mathrm{C} 57 \mathrm{BL} / 6 \mathrm{~J}})$ were

174 included in the experimental setup as a reference group for physiologically normal

175 mice. Mice were maintained on isoflavone-free diet, because it has been recently

176 shown from our laboratory team, that long-term intake of dietary phytoestrogens

177 influences the estrogenic responses in the organism (Moller et al., 2009).

178 The substance administrations were organized as follows. The mice of the po groups

179 had 72 hours access to the experimental chow and the mice of the sc groups were

180 injected at three time points $(0 \mathrm{~h}, 24 \mathrm{~h}$ and $48 \mathrm{~h})$. Subcutaneous injections consisted

181 of castor oil with the substances pre-dissolved in DMSO. The mice of the ArKO

182 control group (CO) and WT group were injected with the carrier solution (DMSO in

183 castor oil) only. For the oral substitution, the substances were blended with the

184 standard diet by the manufacturer in concentrations of $0.5 \mathrm{mg} / \mathrm{kg}$ diet (EE) and 50

$185 \mathrm{mg} / \mathrm{kg}$ diet (PPT, DPN). The average amount of chow taken up by the mice was 186 about $10 \%$ of their bodyweight (BW) per day (data not shown). Therefore, the oral

187 exposure was estimated to $0.05 \mathrm{mg} / \mathrm{kg} \mathrm{BW} / \mathrm{d}$ for EE and $5.0 \mathrm{mg} / \mathrm{kg} \mathrm{BW} / \mathrm{d}$ for the

188 ER-agonists (PPT, DPN). The GEN-rich diet, containing $700 \mu \mathrm{g} / \mathrm{g}$ GEN, was

189 custom-made by LC Laboratories (Woburn, USA). Table 1 summarizes the 190 experimental doses applied in this study.

19124 hours after the last injection and accordingly after $72 \mathrm{~h}$ of exposure to 192 experimental chow, animals were sacrificed by cervical dislocation. The body weight 
193 was measured and blood samples were taken. Uteri and ovaries were collected and

194 weighed after removal of associated fat. For histological analyses, one uterine horn

195 and one ovary per mouse were fixed in buffered formalin-solution (4\%, $\mathrm{pH} 7.4)$. The 196 remaining tissue was snap-frozen in liquid nitrogen for subsequent gene expression 197 analyses.

198 Gonadotropin levels

199 Mouse-specific immunoassay kits (USCN life science \& technology Co., Wuhan, 200 China) were used for in vitro quantitative determination of serum FSH and $\mathrm{LH}$ 201 concentrations. Blood samples were taken post-mortem and allowed to clot before 202 centrifugation (4 $\mathrm{min}$ at $3,000 \times \mathrm{g}$ ) for serum preparation. Serum samples were 203 diluted 1:10 and 1:100 for LH and $\mathrm{FSH}$, respectively, in PBS buffer (pH 7.0 - 7.2) 204 before proceeding according to manufacturer's protocol.

205 Gene expression analyses

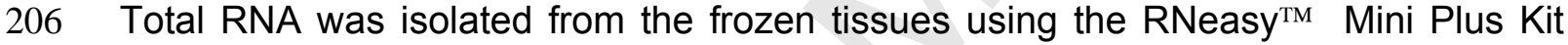
207 (Qiagen) according to the manufacturer's instruction. Three microgram of total RNA 208 of uterine samples and $0.6 \mu \mathrm{g}$ ovarian samples were digested with DNase I 209 (Promega) to eliminate DNA residues, which was checked by real-time PCR. MMLV 210 Reverse Transcriptase (Promega) and oligo-d $(\mathrm{T})_{18}$ primer (MWG; Ebersberg, 211 Germany) were used for cDNA synthesis. The resulting cDNA was amplified by real212 time PCR in the iCycler (Biorad) using Platinum ${ }^{\circledR}$ Taq DNA polymerase (Invitrogen 213 Life Technologies, Karlsruhe, Germany) and the Sybrgreen ${ }^{\circledR}$ detection system 214 (Sigma). All PCR reactions were conducted in triplicates and repeated three times.

215 Relative gene expression levels of target genes were corrected for the expression of 216 the internal reference gene (RPS18; ribosomal protein S18) (Eisenberg and 217 Levanon, 2003, Deroo et al., 2004). RPS18 expression was not influenced by the 218 treatments (data not shown). If not otherwise stated, data were calculated as fold 219 change normalized to carrier-treated ArKO group (CO) using the $\Delta \Delta$ cycle threshold $220(\Delta \Delta \mathrm{CT})$ calculation method (Winer et al., 1999, Pfaffl, 2001).

221 Oligonucleotides used as primers for real-time PCR

222 Based on the DNA sequences available at the UCSC Genome Browser database 223 (http://genome.ucsc.edu/), the following primer pairs were designed to specifically 224 amplify the cDNAs of interest (see Table 2). The primer selection was accomplished 
225 using the software Primer3 (Whitehead Institute for Biomedical Research Cambridge, 226 MA, USA) upon specific parameters. The specificity of the primers was confirmed 227 with the Blat- and in silico PCR tools provided at the UCSC Genome Browser 228 website. All oligonucleotides were synthesized by Eurofins MWG Operon (Ebersberg, 229 Germany). Sequences and amplicon sizes of the primer pairs are listed in Table 2. 230 The efficiency of every PCR reaction was optimized for primer- and magnesium 231 chloride concentrations. All PCR products exhibited a single peak in the melting 232 curve analysis and were identified upon their appropriate amplicon sizes by gel 233 electrophoresis on ethidium bromide agarose gels.

\section{Histological analysis}

235 Formalin-fixed uterine and ovarian tissues of the $\mathrm{CO}$ and the experimental groups 236 were dehydrated and processed for paraffin embedding. Tissue cross sections $237(3 \mu \mathrm{m})$ were processed for hematoxylin-eosin staining to evaluate the 238 histopathological changes of the tissues. The height of the uterine epithelia was 239 determined using a microscope micrometer scale and the program ImageJ 240 (http://rsBWeb.nih.gov/ij). The ovarian cross sections were examined according to 241 their overall morphology and phenotype of follicles and interstitial cells. Unfortunately, 242 there were no tissue samples of the WT tissues available for histological 243 examinations.

244 Immunohistochemisty (IHC) against PCNA Protein

245 Paraffin cross sections of uterine tissues $(1-2 \mu \mathrm{m})$ were rehydrated starting with xylol 246 via grading ethanol to double distilled water. For the IHC, the NOVAdetect anti-rabbit, 247 HRP/DAB kit (Dianova, Hamburg, Germany) was utilized. The IHC protocol was 248 conducted according to the manufacturer's protocol. A specific primary antibody 249 against PCNA (PAI-30254, Affinity BioReagents ${ }^{\mathrm{TM}}$ ) was diluted 1:200 in 5\% milk 250 powder solution and incubated for $2 \mathrm{hr}$ at room temperature.

\section{Statistical analysis}

252 Gene expression data are presented as statistical mean \pm SD of all PCR reactions, 253 which were conducted in triplicates and repeated with three separate cDNAs. If not 254 otherwise stated, relative gene expression levels were documented as fold change 255 against $\mathrm{CO}$, each corrected for the internal reference gene (RPS18). These data 
256 were analysed using the Students $\underline{t}$-Test indicating significant differences versus the 257 CO group $\left({ }^{*} p<0.05\right)$.

258 Furthermore, UWW data were presented in a box plot chart as median with a $10^{\text {th }}$ to $25990^{\text {th }}$ percentile box for a more precise documentation. The statistical analysis of 260 UWW, gonadotropin levels and PCNA immunohistochemical staining was performed 261 using the Mann-Whitney U-test. A value of $p<0.05$ was considered as significantly 262 different from CO.

263 Results

264 Uterine wet weight and epithelia height

265 The uterine wet weights (UWW) and epithelia heights were the main physiological 266 endpoints utilized for the assessment of estrogenicity. The UWW were normalized 267 against the bodyweight and calculated by fold change relative to the ArKO carrier268 treated control group (CO; $1 \pm 0.4$ fold) to obtain a more precise evaluation and a 269 better comparability.

270 As depicted in figure 1, the relative UWW of the WT littermates were 3.7 fold higher

$271(p<0.01)$ than those of CO mice. Irrespective of the route of administration, the 272 treatment with 17a-ethynylestradiol (EE) increased the UWW of ArKO mice even 273 above the WT level (po $7.1 \pm 2.4$ fold and sc $6.9 \pm 1.7$ fold vs. CO; both $p<0.001$ ). 274 Analyzing the effects of the ERa-agonist PPT, the oral administration caused a 275 stronger weight increase $(4.1 \pm 0.9$ fold vs. CO; $p<0.001)$ than the sc injection 276 (2.2 \pm 0.7 fold vs. CO; $p<0.01$ ). Neither genistein (GEN; po $0.9 \pm 0.2$ and sc $2771.1 \pm 0.4$ ) nor $E R \beta$-agonist (DPN; po $1.3 \pm 0.6$; sc $0.8 \pm 0.2$ ) substitution resulted in 278 significant changes of UWW compared to CO.

279 In addition, the morphologies of uterine epithelia for all treatment groups are depicted 280 in figure 2. EE increased the uterine epithelial heights following both administration 281 routes (po $1.5 \pm 0.3$ fold and sc $1.5 \pm 0.2$ fold vs. CO), which was the same for per os 282 administration of PPT (1.5 \pm 0.2 fold vs. CO). In the case of sc administration of PPT, 283 the heights of the uterine epithelia did not change versus $\mathrm{CO}(0.9 \pm 0.1$ fold vs. CO) 284 which was similar in the GEN- as well as the DPN-group, whereby it was noticeable 285 that uteri of DPN-treated mice showed visible changes in overall size and 286 morphology (figure 2 F \& G). 
288

289

290

291

292

293

294

295

296

297

298

299

300

301

302

303

304

305

306

307

308

309

310

311

312

313

314

315

316

317

318

319

\section{Serum gonadotropin levels}

In ArKO mice, serum LH (luteinizing hormone) and FSH (follicle-stimulating hormone) were significantly elevated compared to WT littermates (table 3). The oral administration of the tested substances led to a significant decrease of the $\mathrm{LH}$ and FSH levels, whereas subcutaneous injections engendered a much weaker effect, except for DPN. The subcutaneous effects on the gonadotropin levels were less obvious in the PPT group and not observable for EE. Overall, DPN had only weak but significant influences on the LH and FSH levels. Genistein caused a significant reduction (i.e. back to WT level) of both $\mathrm{LH}$ and FSH serum levels following both administration paths,

\section{Uterine gene and protein expression}

To investigate the molecular mechanisms regarding the sensitivity of ArKO mice uteri to exogenous estrogens, we performed real-time PCR of either genes, related to proliferation or sensitive estrogen-responsive genes.

Although there were obvious differences of relative UWW between CO and WT (figure 1) no significant differences of the proliferation index genes, $\underline{P C N A}$ and $\underline{M K I 67}$ (figure $3 \mathrm{~A}$ and $\mathrm{B}$, respectively) were detected on mRNA level. Following EE and PPT treatment, the expression of proliferation-associated genes was increased either by trend in the case of PCNA or significantly regarding MKI67 $(p<0.05)$ compared to $C O$. On the other hand, oral administration of DPN caused a significant downregulation of PCNA $(p<0.01)$ and MKI67 $(p<0.001)$, even tough sc treatment dose was not effective (figure $3 \mathrm{~A} \& \mathrm{~B}$ ). Furthermore, genistein only had minor influences. In addition, we performed immunohistochemisty $(\mathrm{IHC})$ on the uterine cross sections with an antibody against PCNA protein to confirm the real-time PCR results (figure $3 \mathrm{C}$ ). The amount of the PCNA-positive stained uterine epithelial cells was clearly enhanced following EE and PPT treatment. Additionally, the absence of PCNApositive cells following DPN treatment was detected as well as low numbers in the genistein groups.

Detailed mechanisms of the observed estrogen-responses were first studied by evaluating the gene expression of ESR1 and ESR2 (ERa and ER $\beta$ genes, respectively) by real-time PCR. As expected, in the uterus ESR1 expression was on a markedly higher level than ESR2, as assessed from $\triangle C T$ values. However, the tested substances did not significantly alter the ESR1 expression (figure $4 \mathrm{~A}$ ). On the 
320 other hand, the minorly expressed ER $\beta$ was strongly influenced by the specific

321 treatments (figure $4 \mathrm{~B}$ ). The oral administration of EE and PPT as well as Sc

322 administration of PPT significantly increased the transcription of ESR2 $(p<0.05)$,

323 while DPN and GEN caused minor changes only.

324 Progesterone receptor gene $(\underline{P G R})$, the third steroid receptor analyzed, showed a

325 different expression pattern. In the WT reference group and both EE groups (po and

326 Sc), $\underline{P G R}$ expression was significantly increased compared to CO, while PPT and

327 GEN did not influence, but DPN significantly decreased $\underline{P G R}$ gene expression

328 ( $\mathrm{p}<0.01 \mathrm{po}$; figure $4 \mathrm{C})$.

329 Lactotransferrin gene $(\underline{\underline{L F F})})$, which is a powerful estrogen-responsive gene in the 330 uterus of mice (Toda et al., 2001), was sensitively up-regulated following ERa-

331 stimulation and down-regulated following ERß-activation (figure $5 \mathrm{~A}$ ) in ArKO uteri. In

332 detail, LTF was about 30-fold up-regulated following EE administration (po and sc;

333 both $p<0.05$ ) and about 20 -fold enhanced following oral administration of PPT

334 ( $p<0.05$ vs. CO), thereby rising above the WT expression level $(16.5$ fold, $p<0.05$

335 vs. CO). By contrast, a highly significant reduction of LTF gene expression level was

336 observed following sc injection of DPN (sc 0.3 fold $p<0.001$ ). Additionally, genistein

337 treatment seemingly reduced the expression of $\underline{L T F}$.

338 Complement component $3(\underline{\mathrm{C} 3})$ was an additional estrogen-response gene studied in

339 the uterus of ArKO mice (figure $5 \mathrm{~B}$ ). In ArKO uteri, only EE treatment was able to

340 strongly increase $\underline{C 3}$ expression (4 fold, $p<0.05$ EE sc vs. CO) even beyond WT

341 level (2.3 fold vs. CO). On the other hand, the oral treatment with PPT or GEN

342 exerted only a minor activation ( $p<0.05$ and $p<0.07$ vs. CO, respectively), while

343 DPN did not cause any changes.

\section{Ovarian gene expression}

345 The number of analytical tools to clearly demonstrate effects of ER $\beta$-selective 346 substances is rather limited. This was the motivation to evaluate gene expression 347 profiles of estrogen-regulated genes in the ovaries of ArKO mice. Therefore, we 348 performed real-time PCR of ovarian genes related to either proliferation or 349 differentiation as well as genes known to be influenced by estrogen-signaling in the 350 ovaries.

351 Unexpectedly, there was no detectable ESR1 gene expression in the ovaries of 352 carrier-treated ArKO mice (CO). Therefore, $\triangle \triangle C T$ values of ESR1 real-time 
experiments could not be calculated as fold change vs. CO. Instead, relative gene expressions were corrected for the internal control gene ( $\underline{R P S 18})$ and analyzed by calculating $2^{\wedge}(-\Delta \mathrm{ct})$ to obtain a reliable interpretation (Pfaffl, 2001, Winer et al., 1999). Nevertheless, in ovaries of mice that received estrogenic substances, ESR1 gene was clearly expressed. Additionally, it is important to note that all substances possessed higher impacts on ESR1 gene expression following the oral administration route than those of respective sc groups, as assessed from the $\Delta C T$ values (data not shown).

361 On the other hand, the gene expression levels of ESR2 were clearly higher than the 362 respective ESR1 as evaluated by $\triangle C T$ values (data not shown). In the ovaries of WT 363 mice, ESR2 level was 3.1 fold above $\mathrm{CO}$. As illustrated in figure 6, all substances evidently increased ESR2 level at the administered per os doses (PPT po \& DPN po $p<0.05$, EE po $p=0.06$ vs. CO), whereas subcutaneous doses did not cause significant changes.

In addition, we performed real-time PCR analyses of $\underline{P C N A}$ and luteinizing hormone receptor $(\underline{L H R})$ to evaluate the ovarian proliferation and differentiation status, respectively. $\underline{P C N A}$ gene expression was increased versus $\mathrm{CO}$ following oral substance administrations except for the GEN group (figure 7A). In WT ovaries, LHR was clearly higher expressed than $\mathrm{CO}$, even though no statistical significance could be calculated due to high variances (figure 7B). Although, none of the treatments increased $\underline{L H R}$ gene expression up to WT level, significant up-regulations following PPT ( $p o$ and sc $p<0.05$ vs. CO) or GEN ( $p<0.01$ po vs. CO) treatment were detected (figure 7B).

376 Furthermore, previous studies have demonstrated the emergence of male-like somatic cells in the ovaries of estrogen-depleted mice (Britt et al., 2004, Couse et al., 1999). They reported an influence of estrogen treatment on the gene expression of Sox9 (Sry-like homeobox transcription factor 9) and up- and down-stream factors, which are shown to be related to male-like structures visible in ArKO ovaries (Britt et al., 2004). In the present study, the expression of some of these nuclear transcription factors were examined by real-time PCR: $\underline{S f-1}$ (steroidogenic factor 1) and the related $\underline{L R H-1}$ (liver receptor homologue 1), as well as $\underline{D A X-1}$ (the dosage-sensitive sex reversal adrenal hypoplasia congenital critical region on the $\mathrm{X}$-chromosome gene 1) and SOX-9. In the ovaries of CO mice, the transcription levels of all these 
387 of expression profiles was possible because of very weak gene expressions (data not

388 shown). Nevertheless, in WT ovaries the gene expression levels of all analyzed 389 genes were obviously higher than in $\mathrm{CO}$ or treated ArKO mice ovaries. However, SF$390 \underline{1}$ was significantly up-regulated ( $p<0.05$ vs. CO) in all per os groups, except for

391 GEN (figure 8A). Furthermore, Sc administrations induced minor changes of SF-1 392 gene expression (EE and PPT sc $p<0.05$ ). Regarding $\underline{L R H-1}$ levels, all substances 393 clearly evoked up-regulations (figure $8 \mathrm{~B}$ ).

\section{Discussion}

395 In the last decades, it became apparent that regulations and molecular mechanisms 396 of estrogen and particularly estrogen-like substance actions are far more complex 397 than believed initially. To achieve a better understanding of ER-subtype specific 398 reactions, we analyzed ArKO mice as a totally estrogen-free animal model, which is 399 responsive to exogenous estrogen signals because of both ERs being functional and receptive (Fisher et al., 1998, Toda et al., 2001).

401 This study was intended to qualitatively examine the route of oral substance 402 administration, particularly regarding PPT and DPN treatment and additionally to 403 evaluate ER-specific reactions of ArKO mice. For us, it was important to access a non-invasive route of substance administration which is able to reproduce the consistent effects of subcutaneous injections. Furthermore, not much was initially known about the quality of effects resulting from oral administration of PPT and DPN. Therefore, in our experimental design we have scrutinized two administration groups in parallel (sc and po) for every tested substance. We chose the well-known and wellcharacterized synthetic estrogen $17 \alpha$-ethynylestradiol (EE) as reference substance, firstly for acting via both ER-subtypes and secondly for its oral bioavailability (Inhoffen and Hohlweg, 1938, Kuiper et al., 1997). Regarding the ER-subtype specific substances, we made use of PPT and DPN because they are well described and commercially available. The ERa-specific agonist, propylpyrazole-triol (PPT) has a 410-fold binding preference for ERa over ER $\beta$ (Stauffer et al., 2000). The potencyselective agonist for ER $\beta$ diarylpropionitrile (DPN) has a more than 70-fold higher binding preference for ER $\beta$ than ER (Meyers et al., 2001). For oral administrations, we decided to use 10-fold higher doses because initially we expected oral effects of PPT and DPN to be weaker due to metabolic aspects. Both were applied at doses of 
420 which they were described to be ER-specific (Frasor et al., 2003). In this experiment, 421 per os doses of $50 \mu \mathrm{g}$ EE per $\mathrm{kg} \mathrm{BW}$ and sc doses of $5 \mu \mathrm{g}$ EE / kg BW were applied 422 to assess useful effects in ArKO mice. Finally, genistein (GEN) which is an 423 extensively studied phytoestrogen of the class of isoflavones with mild selective424 agonistic properties on ERß (Kuiper et al., 1997) was included in this study to serve 425 as a natural estrogen-like substance. For GEN treatment, sc doses of $10 \mathrm{mg} / \mathrm{kg} \mathrm{BW}$ 426 and per os doses of $70 \mathrm{mg} / \mathrm{kg}$ BW resulting from the experimental diet were 427 administered to ArKO mice. All these substances were analyzed for their effects in 428 comparison to carrier-treated ArKO mice (CO) and also in relation to untreated wild429 type littermates (WT).

\section{$430 \quad$ Uterine responses of ArKO mice}

431 In this study, the highly sensitive regulations of uterine and ovarian physiology and 432 molecular parameters of ArKO mice were not studied within the light of reproductive 433 biology, but as parameters for characterization of the ER subtype-specific 434 substances. In particular, the uterus of estrogen-deprived animals is known to sensitively react upon activation of ERa signaling by triggering growth and 436 proliferation (Diel et al., 2004).

437 In accordance with other groups, we observed that uteri of carrier-treated ArKO mice 438 were dramatically diminished in uterine size, weight and volume compared to wt 439 siblings (Fisher et al., 1998, Toda et al., 2001). Here, this estrogen-deprivation was 440 mainly observed on dramatically decreased uterine wet weights (UWW), but also the epithelial heights were reduced. As expected, EE and PPT substitution increased both physiological parameters, whereby UWW reactions were more sensitive than epithelial heights, which differs from ovariectomized rats (Diel et al., 2002).

444 On the other hand, no significant alterations of UWW or epithelial heights could be observed following DPN and GEN administration. Moreover, the overall morphology of uteri cross sections of the DPN groups was observably hypoplastic. In this aspect, GEN caused similar patterns like DPN. Additionally, GEN has previously been characterized to have a higher preference for ER $\beta$ (Kuiper et al., 1997). Still, also agonistic properties were described earlier for GEN with a faint increase of UWW in OVX rats after 3 day treatment (Moller et al., 2009). However, short term administration of GEN, even in very high doses, did not result in a steady increase of UWW in OVX rat (Diel et al., 2004). Then again, GEN caused an 
454 ArKO mice, it was shown previously that life-long intake of genistein enriched diets

455 increased uterine and ovarian weights, whereby an association with proliferation was

456 not clear (Britt et al., 2005). Our studies demonstrated an inability of GEN to

457 stimulate the UWW in ArKO mice in the here applied doses. Furthermore, this was

458 correlated with the inability to significantly induce uterine proliferation, which was

459 analyzed on mRNA and protein level. Apparently, there exists a variety of studies

460 including time- and dose-dependencies of uterine actions which indicated SERM-like

461 properties for GEN (Toda et al., 2005, Diel et al., 2001, Diel et al., 2004, Moller et al.,

462 2009). Furthermore, in the context of the biphasic pattern of uterotrophy induced by

463 estrogenic substances, a weak induction of UWW by genistein was previously

464 supposed as a result from imbibitions of water other than from induced proliferation

465 (Diel et al., 2004). In our study, genistein treatment clearly resulted in a reduction of

466 the gonadotropin levels, which is considered as a possibility for estrogen-related

467 effects. Nevertheless, details on proliferation modulation by phytoestrogens need

468 further investigations.

469 Gene expression profiles of ArKO uteri

470 We supported and specified the physiological data by analyzing gene expression

471 levels of two marker genes for proliferation, $\underline{P C N A}$ and $\underline{M K I 67}$. Interestingly, in CO

472 and WT uteri levels of both were on an equal level, even though the UWW were

473 disparate. This could indicate an equilibrium state without exogenous induction.

474 Following EE and PPT treatment, gene expression of both proliferation-associated

475 genes was highly stimulated, in accordance with UWW results. In contrast, oral

476 administration of DPN caused a significant reduction of proliferation markers on

477 mRNA and protein level. Previously, Frasor et al. (2003) demonstrated that the ER $\beta$ -

478 specific agonist DPN has a very limited ability to stimulate proliferation in the uterus

479 as well as causing a $30 \%$ reduction of the PPT-stimulated UWW increase. It is widely

480 accepted that ER $\beta$-signaling is unable to induce uterine growth and proliferation,

481 which was among others clearly demonstrated in the aERKO mice (reviewed by

482 Couse and Korach, 1999). Nevertheless, the reported DPN effects in ArKO mice,

483 which were detectable on mRNA and on protein level, were rather unexpected and 484 need further confirmation.

485 We increased the analytical spectrum of the uterotrophic assay by including gene 486 expression analyses of estrogen-responsive genes. First, we analyzed the estrogen 487 receptor status and the progesterone receptor expression to itemize the proliferation 
and differentiation status of uterine tissue in more detail and to prove the ability of ArKO mice's uteri to respond directly to estrogenic signals. ESR1 gene expression levels in CO were similar to WT. Even though the ESR1 levels markedly exceeded that of ESR2, we hardly observed an alteration following substance administration. This stands in contrast to effects previously observed in rat uteri, where $17 \beta$-estradiol down-regulated both ESR1 and ESR2 expression (Zierau et al., 2008).

In this study, only oral administration of DPN significantly decreased ERa levels. Mechanistically, it was shown previously that ER $\beta$ could serve to inhibit ER $\alpha$ signalling in target tissues (Frasor et al., 2003, Hall and McDonnell, 1999), maybe this is realized also by influencing gene expression. Additionally, the low ER $\beta$ gene expression levels in the uterus were significantly increased upon EE (per os) and PPT treatment, although never reaching ERa level. These observations were rather unexpected and stand in contrast to various other studies, which reported a reduction of both ER $\alpha$ and ER $\beta$ expression upon estrogen treatments (Diel et al., 2004, Pillai et al., 2002). According to Weihua and colleagues, ER $\beta$ tends to down-regulate ERa activity (Weihua et al., 2000). In the present study, it seems that ERa activation increases ER $\beta$ expression and ER $\beta$ activation inhibits ERa expression. This may add an interesting aspect to the complexity of estrogenic cross talk in regulating networks, including feedback regulations of their own receptors.

Even though ER $\beta$ expression was increased, the dominant role of ERa stayed immanently superior in the uterus also in the estrogen-free background of ArKO mice. Diel et al. described that a high ERa /ER $\beta$ ratio was correlated with increased proliferation (Diel et al., 2004). Here we observed that only upon stimulation of ERa signaling in combination with a high ERa / ER $\beta$ ratio proliferation was switched on, whereas activating only ER $\beta$ even with a high ERa /ER $\beta$ ratio was not sufficient to increase proliferation.

Adding to the understanding of potential molecular mechanisms of regulations in the uterus, we have analyzed three estrogen-response genes: progesterone receptor $(\underline{P G R})$, lactotransferrin $(\underline{L T F})$ and complement component 3, $(\underline{C 3})$. All three genes contain estrogen-response elements in their 5'-regulatory regions (O'Lone et al., 2004) and are described earlier to be directly regulated by estrogens (Toda et al., 2001, Zierau et al., 2008). Here, all were clearly up-regulated by EE treatment in the uteri of ArKO mice. In this experimental design, LTF was the most sensitive estrogen-response gene with an expected increase of gene expression following 
522 ERa activation. DPN added a more interesting aspect, because subcutaneous

523 administration led to a highly significant down-regulation of $\underline{L T F}$. In accordance,

524 Couse et al. found no up-regulation of lactotransferrin as well as progesterone

525 receptor in the uteri of aERKO upon estrogenic signals, but no down-regulation was 526 observed so far. It needs further investigations to analyze details of ER-specificity of 527 ERE-dependent mechanism and their responsibilities for the observed effect. 528 Another explanation might as well be alternative pathways of LTF gene regulation 529 involving activation of cAMP or growth factor response elements, which were found 530 in the promoter region of this gene (Shi and Teng, 1996, Teng et al., 1998). C3 531 revealed a similar but weaker profile in ArKO uteri, which was surprising, because in 532 the OVX rats C3 is a very strong estrogenic-marker (Diel et al., 2004, Zierau et al., 533 2008). Here, we could only speculate about species specificities or even side effects 534 resulting from ovariectomy, but no definite explanation can be given for that result.

535 PGR, which is an important steroid receptor in the uterus, revealed an interesting 536 seemingly ER-specific expression pattern in the uteri of differentially treated ArKO 537 mice. In WT mice and in ArKO mice following EE administration, $\underline{P G R}$ expression 538 levels were significantly elevated compared to CO. The ERa-agonist (PPT) did not 539 influence, while the ER $\beta$-agonist (DPN) significantly decreased $\underline{P G R}$ expression. It is 540 known, that $\underline{P G R}$ is transcribed under the regulation of estrogens (Toda et al., 2001), 541 although differential expression patterns are described in the literature regarding 542 effects following estrogen treatments (Waters et al., 2001, Adashi and Hsueh, 1982).

543 There might be dose-dependent or ER-subtype specific regulation patterns involved, 544 but also a time-dependent regulation has been demonstrated for $\underline{P G R}$ (Zierau et al., 545 2008). Furthermore, the 5' region of $\underline{P G R}$ gene contains a lot of regulatory 546 sequences, including EREs, PREs, AP1-binding sites and others (Hagihara et al., 547 1994) which implies a complex molecular regulation pattern. ArKO mice might add to 548 the understanding of regulations of $\underline{P G R}$ expression, because in contrast to OVX or 549 immature in vivo models, progesterone production is not compromised.

\section{$550 \quad$ Gene expression profiles of ArKO ovaries}

551 Ovaries were examined because they represent a target organ with high ER $\beta$ 552 distribution (Drummond et al., 2002) and may be useful to evaluate in particular the 553 ERß-specific actions of the tested substances. Unfortunately, the measured ovarian 554 weights as well as the morphological analysis of ovarian cross sections were not 555 convincing enough for a conclusive comparison of substance responses (data not 
556 shown). Probably, the three-day treatment period was not sufficient to abundantly

557 influence ovarian phenotypes. Nevertheless, we used the ovaries of differentially

558 treated ArKO mice to isolate RNA and analyze estrogen-responsiveness by gene

559 expression analysis. In the ovaries, ESR2 was highly expressed but hardly

560 influenced by the treatments. Although, there were no transcripts of ESR1 detectable

561 in ovaries of CO, ESR1 transcription was switched on following application of the

562 substances, irrespective of the type of ligand. This shows the capacity of ArKO

563 ovaries to respond directly via both ERs upon stimulation.

564 Additionally, we were examining the ovarian proliferation and differentiation status.

565 Thereby, the LH-receptor status served as indicator for differentiation, because of its

566 association with improved morphology (Britt et al., 2004) and its expression

567 described to increase in antral follicles (Nimrod et al., 1977). The WT ovaries

568 displayed the most differentiated profile according to high LHR gene expression,

569 whereas in $\mathrm{CO}$ the lowest levels were detected. None of the treatments led to

570 significant alterations compared to $\mathrm{CO}$ level. There could also be a connection to

571 serum LH levels which are known to decrease $\underline{\text { LHR }}$ expression (Nimrod et al., 1977,

572 Richards, 1975).

573 Furthermore, we investigated the ovarian proliferation status by analyzing the

574 expression levels of $\underline{P C N A}$. Identical to the findings in the uterus, CO and WT level

575 did not significantly differ in their profile. Hence, significant induction of proliferation

576 was detected following EE and PPT (po) and in tendency DPN administration.

577 According to Britt et al., ovarian weights were dependant on specific treatment, which

578 should be taken into account in further studies (Britt et al., 2005, Britt et al., 2004).

579 Since previous studies described the emergence of male somatic cells in the ovaries

580 of estrogen-depleted mice and described an improvement by administration of

581 estrogenic substances (Britt et al., 2004, Couse et al., 1999), we used these

582 steroidogenic marker genes to evaluate their expression pattern in specifically

583 treated ArKO mice. All these genes encode for nuclear transcription factors, which

584 are naturally involved in the gonadal development. A high expression of Sox9 and

585 changes of up- and down-stream regulating factors $(\underline{S F-1}, \underline{L R H-1}$ and $\underline{D A X-1})$ are

586 responsible for the male-like phenotype of the gonads (Britt et al., 2004). In CO, the

587 gene expression level of all of these transcription factors were very close to the

588 detection limit. In our experimental setup, these genes, which were regulated by Britt

589 and colleagues, were not abundantly influenced in our three-day assay. Perhaps, the 
590 treatment period was too short or the experimental dosages were too low for

591 influencing ovarian mechanisms. It is also possible that 16-wk old mice were already

592 too old for evaluating pattern of those development related genes. It is conversant

593 that the microenvironment of the ovaries has a great importance because it is flooded

594 with high doses of estrogenic substances. Furthermore, activated intraovarian auto-

595 regulatory feedback mechanisms play a role in maturation of the ovaries (Adashi and

596 Hsueh, 1982, lida et al., 1991). In this study, we can not find a conclusive answer to

597 the functional aspects. Nevertheless, it was clearly evident that the substances

598 provoked a greater effect following the oral doses. Probably, the sc injection doses

599 were too weak to possess effects in the ovaries lifespan.

\section{$600 \quad$ Influence on gonadotropins}

601 In accordance with Fisher et al., we observed elevated gonadotropin levels in female

602 ArKO mice (Fisher et al., 1998). This reflects a disruption of negative feedback on the

603 hypothalamic-pituitary axis leading to elevated gonadotropin levels. In our study, we

604 observed a reversion of these levels back to or even below WT level by application of

605 ERa-agonists. However, the effects of estrogenic substances on serum LH and FSH

606 levels were complex, whereby the effects resulting from oral administration gave a

607 clearer pattern. PPT as well as EE strongly decreased LH and FSH back or even

608 below to WT level, respectively. Surprisingly, results from the EE sc did not show any

609 effect, which may be a dose effect. There is an importance of ERa signaling for LH

610 feedback suggested by Couse et al., who showed that LH levels were increased in

$611 \alpha$ ERKO and $\alpha \beta E R K O$ mice compared with Wt and $\beta E R K O$ mice (Couse et al., 2003).

612 However, they observed a normal FSH regulation in aERKO and aßERKO females.

613 Our data showed a decrease of FSH level following ERa- as well as ERß-agonist

614 treatment, which indicates a role for ERß-dependent regulation, but also other

615 regulation mechanisms like those via inhibin/activin add to complexity (Couse et al.,

616 2003).

617 Finally, genistein possessed its most obvious effects in ArKO mice by the reduction

618 of LH and FSH levels. This effect was previously described by Britt et al., whereby

619 Gen+ diet significantly reduced FSH levels in ArKO mice, although the exact

620 mechanisms has not been defined (Britt et al., 2005). There might be an induction of

621 estrogenic effects from GEN by influencing gonadotropin release. The doses used for

622 GEN treatments were previously described to induce specific effects in OVX rats

623 (Diel et al., 2004, Moller et al., 2009). In ArKO mice, they need to be further 
624 investigated, because they were inefficient, which could be due to species specificity

625 or due to different estrogenic background levels and developmental histories of the

626 animal model.

\section{Summary}

628 In summary, we could demonstrate that ArKO mice respond very sensitively and 629 reliably upon supplementation of estrogenic substances on both administration 630 routes and were fulfilling the expectations of the classical uterotrophic assay. PPT 631 induced typical estrogenic responses in the uterus on analyzed physiological 632 endpoints and on expression of estrogen-response genes with stronger effects upon 633 oral administration. The weaker sc effects probably resulted from a sub-optimal sc 634 dosage versus an efficient oral dosage. For a quantitative comparison of oral versus 635 subcutaneous effects equal doses need to be used.

636 We observed some novel and interesting expression profiles following DPN 637 treatments, which were not related to a modulation of ER $\alpha$ effects but seemingly ER $\beta$ 638 effects only. There was no uterotrophy recognized, UWW remained at control level. 639 Furthermore, proliferation markers were significantly inhibited by DPN. Additionally, 640 in the uterus estrogen-response genes were regulated in the opposite direction as by

641 ERa signaling. We reported decreasing levels of $\underline{P G R}$ and $\underline{L T F}$ gene expression. In 642 addition, $\underline{C 3}$ expression was not altered at all by DPN treatment. Those results 643 clearly exemplify so called anti-estrogenic properties in the uterus of ArKO mice 644 which are seemingly ERß-related effects. Finally, we can state that DPN doses used 645 in this experiment were sufficient to activate ER $\beta$-specific actions which need to be 646 confirmed for their reliability in further experiments, but not ERa-specific effects.

647 GEN treatment did not exhibit strong effects under the utilized experimental 648 conditions and hardly effected the expression of the analyzed estrogen-response 649 genes, but clearly influenced the release of gonadotropins.

650 Regarding the administration routes, we were aiming to evaluate effects resulting 651 from oral application of PPT and DPN. We chose 10-fold higher doses on the oral 652 route, because we initially expected lower effects than finally observed. For reaching 653 a quantitative comparison of different administration routes equal doses should be 654 applied in further experiments. Overall, effects resulting from EE treatments were 655 less dose- and route-dependent, whereas for PPT, per os dose led to more obvious 656 effects than sc injections, for instance an increase of UWW or proliferation markers. 657 This might indicate that sc doses of $500 \mu \mathrm{g} / \mathrm{kg}$ BW are suboptimal to observe 
658 reliable effects in ArKO mice in a three day assay, whereas the higher per os doses 659 were efficient and might be a basis for further experiments in ArKO mice, but still 660 need to be confirmed for long-term usage.

661 


\section{Acknowledgements}

662 The authors are very grateful to Dena Amer for critical reading and editing the 663 manuscript. We would like to thank the team of the Institute for Pathology 664 (Technische Universität Dresden) for their help during histological slides 665 preparations. This work was supported by the Deutsche Krebsforschungsstiftung.

666 Declaration of interest statement

667 The authors have declared no conflict of interest.

668 
668

669

670

671

672

673

674

675

676

677

678

679

680

681

682

683

684

685

686

687

688

689

690

691

692

693

694

695

696

697

698

699

\section{References}

Adashi, E. Y. \& Hsueh, A. J. (1982) Estrogens augment the stimulation of ovarian aromatase activity by follicle-stimulating hormone in cultured rat granulosa cells. J Biol Chem. 257, 6077-6083.

Britt, K. L., Simpson, E. R. \& Findlay, J. K. (2005) Effects of phytoestrogens on the ovarian and pituitary phenotypes of estrogen-deficient female aromatase knockout mice. Menopause. 12, 174-185.

Britt, K. L., Stanton, P. G., Misso, M., Simpson, E. R. \& Findlay, J. K. (2004) The effects of estrogen on the expression of genes underlying the differentiation of somatic cells in the murine gonad. Endocrinology. 145, 3950-3960.

Couse, J. F., Hewitt, S. C., Bunch, D. O., Sar, M., Walker, V. R., Davis, B. J. \& Korach, K. S. (1999) Postnatal sex reversal of the ovaries in mice lacking estrogen receptors alpha and beta. Science. 286, 2328-2331.

Couse, J. F. \& Korach, K. S. (1999) Estrogen receptor null mice: what have we learned and where will they lead us? Endocr Rev. 20, 358-417.

Couse, J. F., Yates, M. M., Walker, V. R. \& Korach, K. S. (2003) Characterization of the hypothalamic-pituitary-gonadal axis in estrogen receptor (ER) Null mice reveals hypergonadism and endocrine sex reversal in females lacking ERalpha but not ERbeta. Mol Endocrinol. 17, 1039-1053.

Deroo, B. J., Hewitt, S. C., Peddada, S. D. \& Korach, K. S. (2004) Estradiol regulates the thioredoxin antioxidant system in the mouse uterus. Endocrinology. 145, 5485-5492.

Diel, P., Geis, R. B., Caldarelli, A., Schmidt, S., Leschowsky, U. L., Voss, A. \& Vollmer, G. (2004) The differential ability of the phytoestrogen genistein and of estradiol to induce uterine weight and proliferation in the rat is associated with a substance specific modulation of uterine gene expression. Mol Cell Endocrinol. 221, 21-32.

Diel, P., Schmidt, S. \& Vollmer, G. (2002) In vivo test systems for the quantitative and qualitative analysis of the biological activity of phytoestrogens. J Chromatogr $B$ Analyt Technol Biomed Life Sci. 777, 191-202.

Diel, P., Smolnikar, K., Schulz, T., Laudenbach-Leschowski, U., Michna, H. \& Vollmer, G. (2001) Phytoestrogens and carcinogenesis-differential effects of 
genistein in experimental models of normal and malignant rat endometrium. Hum Reprod. 16, 997-1006.

Drummond, A. E., Baillie, A. J. \& Findlay, J. K. (1999) Ovarian estrogen receptor alpha and beta mRNA expression: impact of development and estrogen. Mol Cell Endocrinol. 149, 153-161.

Drummond, A. E., Britt, K. L., Dyson, M., Jones, M. E., Kerr, J. B., O'donnell, L., Simpson, E. R. \& Findlay, J. K. (2002) Ovarian steroid receptors and their role in ovarian function. Mol Cell Endocrinol. 191, 27-33.

Eisenberg, E. \& Levanon, E. Y. (2003) Human housekeeping genes are compact. Trends Genet. 19, 362-365.

Fisher, C. R., Graves, K. H., Parlow, A. F. \& Simpson, E. R. (1998) Characterization of mice deficient in aromatase (ArKO) because of targeted disruption of the cyp19 gene. Proc Natl Acad Sci U S A. 95, 6965-6970.

Frasor, J., Barnett, D. H., Danes, J. M., Hess, R., Parlow, A. F. \& Katzenellenbogen, B. S. (2003) Response-specific and ligand dose-dependent modulation of estrogen receptor (ER) alpha activity by ERbeta in the uterus. Endocrinology. 144, 3159-3166.

Green, S., Walter, P., Kumar, V., Krust, A., Bornert, J. M., Argos, P. \& Chambon, P. (1986) Human oestrogen receptor cDNA: sequence, expression and homology to v-erb-A. Nature. 320, 134-139.

Greene, G. L., Gilna, P., Waterfield, M., Baker, A., Hort, Y. \& Shine, J. (1986) Sequence and expression of human estrogen receptor complementary DNA. Science. 231, 1150-1154.

Hagihara, K., Wu-Peng, X. S., Funabashi, T., Kato, J. \& Pfaff, D. W. (1994) Nucleic acid sequence and DNase hypersensitive sites of the $5^{\prime}$ region of the mouse progesterone receptor gene. Biochem Biophys Res Commun. 205, 10931101.

Hall, J. M. \& Mcdonnell, D. P. (1999) The estrogen receptor beta-isoform (ERbeta) of the human estrogen receptor modulates ERalpha transcriptional activity and is a key regulator of the cellular response to estrogens and antiestrogens. Endocrinology. 140, 5566-5578.

Heldring, N., Pike, A., Andersson, S., Matthews, J., Cheng, G., Hartman, J., Tujague, M., Strom, A., Treuter, E., Warner, M. \& Gustafsson, J. A. (2007) Estrogen 
733

734

735

736

737

738

739

740

741

742

743

744

745

746

747

748

749

750

751

752

753

754

755

756

757

758

759

760

761

762

763

764

765

766

receptors: how do they signal and what are their targets. Physiol Rev. 87, 905931.

lida, K., Imai, A. \& Tamaya, T. (1991) Stimulatory effects of estrogen on gonadotropin-releasing hormone-induced phosphoinositide turnover in granulosa cells. J Steroid Biochem Mol Biol. 38, 583-586.

Inhoffen, H. H. \& Hohlweg, W. (1938) Neue per os-wirksame weibliche Keimdrüsenhormon-Derivate: 17-Aethinyl-oestradiol und Pregnen-in-on-3-ol17 Naturwissenschaften. 26, 96.

Kanno, J., Onyon, L., Haseman, J., Fenner-Crisp, P., Ashby, J. \& Owens, W. (2001) The OECD program to validate the rat uterotrophic bioassay to screen compounds for in vivo estrogenic responses: phase 1. Environ Health Perspect. 109, 785-794.

Krege, J. H., Hodgin, J. B., Couse, J. F., Enmark, E., Warner, M., Mahler, J. F., Sar, M., Korach, K. S., Gustafsson, J. A. \& Smithies, O. (1998) Generation and reproductive phenotypes of mice lacking estrogen receptor beta. Proc Natl Acad Sci U S A. 95, 15677-15682.

Kuiper, G. G., Carlsson, B., Grandien, K., Enmark, E., Haggblad, J., Nilsson, S. \& Gustafsson, J. A. (1997) Comparison of the ligand binding specificity and transcript tissue distribution of estrogen receptors alpha and beta. Endocrinology. 138, 863-870.

Kuiper, G. G., Enmark, E., Pelto-Huikko, M., Nilsson, S. \& Gustafsson, J. A. (1996) Cloning of a novel receptor expressed in rat prostate and ovary. Proc Natl Acad Sci U S A. 93, 5925-5930.

Kurita, T., Lee, K., Saunders, P. T., Cooke, P. S., Taylor, J. A., Lubahn, D. B., Zhao, C., Makela, S., Gustafsson, J. A., Dahiya, R. \& Cunha, G. R. (2001) Regulation of progesterone receptors and decidualization in uterine stroma of the estrogen receptor-alpha knockout mouse. Biol Reprod. 64, 272-283.

Meyers, M. J., Sun, J., Carlson, K. E., Marriner, G. A., Katzenellenbogen, B. S. \& Katzenellenbogen, J. A. (2001) Estrogen receptor-beta potency-selective ligands: structure-activity relationship studies of diarylpropionitriles and their acetylene and polar analogues. J Med Chem. 44, 4230-4251.

Moller, F. J., Zierau, O., Hertrampf, T., Bliedtner, A., Diel, P. \& Vollmer, G. (2009) Long-term effects of dietary isoflavones on uterine gene expression profiles. $J$ Steroid Biochem Mol Biol. 113, 296-303. 
767 Mosselman, S., Polman, J. \& Dijkema, R. (1996) ER beta: identification and

768

769

770

771

772

773

774

775

776

777

778

779

780

781

782

783

784

785

786

787

788

789

790

791

792

793

794

795

796

797

798

799

800 characterization of a novel human estrogen receptor. FEBS Lett. 392, 49-53.

Nimrod, A., Bedrak, E. \& Lamprecht, S. A. (1977) Appearance of LH-receptors and LH-stimulable cyclic AMP accumulation in granulosa cells during follicular maturation in the rat ovary. Biochem Biophys Res Commun. 78, 977-984.

O'lone, R., Frith, M. C., Karlsson, E. K. \& Hansen, U. (2004) Genomic targets of nuclear estrogen receptors. Mol Endocrinol. 18, 1859-1875.

Odum, J., Lefevre, P. A., Tittensor, S., Paton, D., Routledge, E. J., Beresford, N. A., Sumpter, J. P. \& Ashby, J. (1997) The rodent uterotrophic assay: critical protocol features, studies with nonyl phenols, and comparison with a yeast estrogenicity assay. Regul Toxicol Pharmacol. 25, 176-188.

Pelletier, G. \& El-Alfy, M. (2000) Immunocytochemical localization of estrogen receptors alpha and beta in the human reproductive organs. J Clin Endocrinol Metab. 85, 4835-4840.

Pfaffl, M. W. (2001) A new mathematical model for relative quantification in real-time RT-PCR. Nucleic Acids Res. 29, e45.

Pillai, S. B., Jones, J. M. \& Koos, R. D. (2002) Treatment of rats with 17beta-estradiol or relaxin rapidly inhibits uterine estrogen receptor beta1 and beta2 messenger ribonucleic acid levels. Biol Reprod. 67, 1919-1926.

Richards, J. S. (1975) Estradiol receptor content in rat granulosa cells during follicular development: modification by estradiol and gonadotropins. Endocrinology. 97, 1174-1184.

Rider, V. (2002) Progesterone and the control of uterine cell proliferation and differentiation. Front Biosci. 7, d1545-1555.

Saarinen, N. M., Bingham, C., Lorenzetti, S., Mortensen, A., Makela, S., Penttinen, P., Sorensen, I. K., Valsta, L. M., Virgili, F., Vollmer, G., Warri, A. \& Zierau, O. (2006) Tools to evaluate estrogenic potency of dietary phytoestrogens:A consensus paper from the EU Thematic Network "Phytohealth" (QLKI-20022453). Genes Nutr. 1, 143-158.

Shi, H. \& Teng, C. (1996) Promoter-specific activation of mouse lactoferrin gene by epidermal growth factor involves two adjacent regulatory elements. Mol Endocrinol. 10, 732-741.

Simpson, E. R. (2004) Models of aromatase insufficiency. Semin Reprod Med. 22, 25-30. 
801 Stauffer, S. R., Coletta, C. J., Tedesco, R., Nishiguchi, G., Carlson, K., Sun, J., 802 Katzenellenbogen, B. S. \& Katzenellenbogen, J. A. (2000) Pyrazole ligands: 803 structure-affinity/activity relationships and estrogen receptor-alpha-selective 804 agonists. J Med Chem. 43, 4934-4947.

805 Teng, C., Shi, H., Yang, N. \& Shigeta, H. (1998) Mouse lactoferrin gene. Promoter806 specific regulation by EGF and cDNA cloning of the EGF-response-element $807 \quad$ binding protein. Adv Exp Med Biol. 443, 65-78.

808 Toda, K., Hayashi, Y., Okada, T., Morohashi, K. \& Saibara, T. (2005) Expression of 809 the estrogen-inducible EGFP gene in aromatase-null mice reveals differential 810 tissue responses to estrogenic compounds. Mol Cell Endocrinol. 229, 119811126.

812 Toda, K., Takeda, K., Okada, T., Akira, S., Saibara, T., Kaname, T., Yamamura, K., 813 Onishi, S. \& Shizuta, Y. (2001) Targeted disruption of the aromatase P450 814 gene (Cyp19) in mice and their ovarian and uterine responses to 17beta815 oestradiol. J Endocrinol. 170, 99-111.

816 Waters, K. M., Safe, S. \& Gaido, K. W. (2001) Differential gene expression in 817 response to methoxychlor and estradiol through ERalpha, ERbeta, and AR in 818 reproductive tissues of female mice. Toxicol Sci. 63, 47-56.

819 Weihua, Z., Saji, S., Makinen, S., Cheng, G., Jensen, E. V., Warner, M. \& 820 Gustafsson, J. A. (2000) Estrogen receptor (ER) beta, a modulator of ERalpha $821 \quad$ in the uterus. Proc Natl Acad Sci U S A. 97, 5936-5941.

822 Winer, J., Jung, C. K., Shackel, I. \& Williams, P. M. (1999) Development and 823 validation of real-time quantitative reverse transcriptase-polymerase chain 824 reaction for monitoring gene expression in cardiac myocytes in vitro. Anal $825 \quad$ Biochem. 270, 41-49.

826 Zierau, O., Kretzschmar, G., Moller, F., Weigt, C. \& Vollmer, G. (2008) Time 827 dependency of uterine effects of naringenin type phytoestrogens in vivo. Mol $828 \quad$ Cell Endocrinol. 294, 92-99.

829 830 
830

831

832

833

834

835

836

837

838

839

\section{Tables:}

Table 1 Experimental doses of estrogenic substances.

\begin{tabular}{|l|c|c|}
\hline & \multicolumn{2}{|c|}{ doses in $\mathrm{mg} / \mathrm{kg} \mathrm{BW} / \mathrm{d}$} \\
\hline substance & sc injection & Av. per os substitution \\
\hline EE & 0.005 & 0.05 \\
\hline PPT & 0.5 & 5.0 \\
\hline DPN & 0.5 & 5.0 \\
\hline GEN & 10.0 & 70.0 \\
\hline
\end{tabular}

Details for the substance administrations are described in material and methods.

Table 3 Effects of estrogenic substances on gonadotropin levels in ArKO mice following either oral (po) or subcutaneous (sc) administration in comparison to female WT littermates.

LH in $\mu \mathrm{IU} / \mathrm{ml}$

FSH in $\mathrm{mIU} / \mathrm{ml}$

\begin{tabular}{|r|ll|l|}
\hline ArKO & $94 \pm 6$ & $44 \pm 9$ \\
\hline WT & \multicolumn{2}{|c|}{$47 \pm 22^{* *}$} & $29 \pm 2^{*}$ \\
\hline & po & $47 \pm 25^{* *}$ & $26 \pm 9^{*}$ \\
EE & sc & $91 \pm 39$ & $40 \pm 5$ \\
\hline & po & $30 \pm 13^{*}$ & $17 \pm 6^{* *}$ \\
PPT & sc & $46 \pm 24^{*}$ & $39 \pm 10$ \\
\hline & po & $73 \pm 52$ & $23 \pm 3^{* *}$ \\
DPN & sc & $63 \pm 18^{* *}$ & $32 \pm 8^{*}$ \\
\hline & po & $30 \pm 14^{* *}$ & $25 \pm 2^{* *}$ \\
GEN & sc & $28 \pm 14^{* *}$ & $30 \pm 4^{*}$ \\
\hline
\end{tabular}

840 Data are expressed as mean \pm SD (in $\mu \mathrm{lU} / \mathrm{ml}$ and $\mathrm{mlU} / \mathrm{ml}$ for $\mathrm{LH}$ (luteinizing hormone) and

841 FSH (follicle-stimulating hormone), respectively. (IU meaning international units)

$842{ }^{*} p<0.05$ and ${ }^{* *} p<0.01$ versus ArKO control according to Mann-Whitney-U-test. 
Table 2 Oligonucleotides used as primers for the real-time PCR to analyse uterine and ovarian gene expression profile are listed in alphabetical order.

\begin{tabular}{|c|c|c|c|c|}
\hline $2 \times$ & gene & & sequence ( $\left.5^{\prime}-3^{\prime}\right)$ & $\begin{array}{l}\text { amplicon } \\
\text { size (bp) }\end{array}$ \\
\hline \multirow{2}{*}{ complement component 3} & \multirow[b]{2}{*}{ C3 } & fwd & CCAGCAGGTCATCAAGTCAG & \multirow{2}{*}{185} \\
\hline & & rev & ACGTGTCCTTCCCAATGATG & \\
\hline \multirow{2}{*}{$\begin{array}{l}\text { dosage-sensitive sex reversal adrenal hypoplasia congenital critical region on } \\
\text { the X-chromosome gene } 1\end{array}$} & \multirow{2}{*}{$\begin{array}{c}\text { DAX-1 } \\
\text { (Nrob1) }\end{array}$} & fwd & TCAGGAAGAGCGAGAGGTG & \multirow{2}{*}{186} \\
\hline & & rev & CTGGCGTTGGTGAGCATAG & \\
\hline \multirow{2}{*}{ estrogen receptor $\alpha$} & \multirow{2}{*}{ ESR1 } & fwd & TGTTTGCTCCTAACTTGCTCCT & \multirow{2}{*}{222} \\
\hline & & rev & GGTGGATGTGGTCCTTCTCTT & \\
\hline \multirow{2}{*}{ estrogen receptor $\beta$} & \multirow{2}{*}{ ESR2 } & fwd & GCCAGGAAGCAGAGAGTAGC & \multirow{2}{*}{189} \\
\hline & & rev & TCATGCTGAGCAGATGTTCC & \\
\hline \multirow{2}{*}{ luteinizing hormone/choriogonadotropin receptor } & \multirow{2}{*}{ LHR } & fwd & TCAATGGGACGACGCTAATC & \multirow{2}{*}{205} \\
\hline & & rev & CTGGAGGGCAGAGTTTTCAG & \\
\hline \multirow{2}{*}{ liver receptor homologue 1} & \multirow{2}{*}{$\begin{array}{l}\text { LRH-1 } \\
(\mathrm{Nr} 5 \mathrm{a} 2)\end{array}$} & fwd & ATGGGAAGGAAGGGACAATC & \multirow{2}{*}{183} \\
\hline & & rev & TGAACAGCACCAGGAACTTG & \\
\hline \multirow{2}{*}{ lactotransferrin } & \multirow{2}{*}{$L T F$} & fwd & GCAAAACCACATCGGAGAAG & \multirow[b]{2}{*}{204} \\
\hline & & rev & GGGAGTGAGGAGACCAGATG & \\
\hline \multirow{2}{*}{ antigen identified by monoclonal antibody Ki 67} & \multirow{2}{*}{ MKI67 } & fwd & CCAAGGGTAACTCGTGGAAC & \multirow{2}{*}{242} \\
\hline & & rev & TCCTTAAACTCAGGCAGTAGCAG & \\
\hline \multirow{2}{*}{ proliferating cell nuclear antigen } & \multirow{2}{*}{ PCNA } & fwd & ACATTGGAGATGCTGTTGTGA & \multirow{2}{*}{206} \\
\hline & & rev & CAGTGGAGTGGCTTTTGTGA & \\
\hline \multirow{2}{*}{ progesterone receptor } & \multirow{2}{*}{$P G R$} & fwd & CTGGCATGGTCCTTGGAG & \multirow{2}{*}{246} \\
\hline & & rev & TGGAAGTGTCAGGCTTTGTG & \\
\hline \multirow{2}{*}{ ribosomal protein S18 } & \multirow{2}{*}{ RPS18 } & fwd & AGGATGTGAAGGATGGGAAG & \multirow{2}{*}{187} \\
\hline & & rev & TTGGATACACCCACAGTTCG & \\
\hline cteroidogenir factor 1 & SF-1 & fwd & GAGTTCGTCTGTCTCAAGTTCC & 179 \\
\hline steroldogenic tactor 1 & (Nr5a1) & rev & ACCTCCACCAGGCACAATAG & $1 / 9$ \\
\hline & & fwd & CGGAGGAAGTCGGTGAAG & \\
\hline sry-like homeobox trar & $50 \times-9$ & rev & GTCGGTTTTGGGAGTGGTG & 201 \\
\hline
\end{tabular}




\section{Figure captions:}

Figure 1. Relative uterine wet weights (UWW) of the differentially treated groups of ArKO mice.

Mice were treated according to the experimental design as described in material and methods and results are normalized against the carrier-treated $\mathrm{CO}$ group. The box plot shows the 90th to the 10th percentiles (box), the median (+) in addition to the minimum and maximum values. Statistical analyses were performed using the Mann Whitney $\underline{U}$-test. The hash signs indicate the significant differences to $\mathrm{CO}$, with $p<0.01$ (\#\#) and $p<0.001$ (\#\#). The highly significant difference between the CO and normal WT is indicated by '++'. The significant effects of per os versus the subcutaneous administration is indicated by ** $(p<0.01)$.

Figure 2. Light micrographs showing representative uteri cross sections ( $3 \mu \mathrm{m})$ of ArKO mice in differential experimental groups

(A) CO; (B) EE po; (C) EE sc; (D) PPT po; (E) PPT sc; (F) DPN po; (G) DPN sc; (H) GEN po; (I) GEN sc. The histological sections were stained with hematoxylin-eosin and documented at a magnification of $200 x$ (black bar $=50 \mu \mathrm{m}$ ).

Figure 3. Gene and protein expression profiles of proliferation-associated genes in the uterus of differentially treated ArKO mice are analyzed upon two administration routes, per os and subcutaneous.

Relative gene expression levels of (A) $\underline{P C N A}$ and (B) $\underline{M K I 67}$ are normalized against the CO group (black horizontal line). Data are presented as mean \pm SD. Statistical analyses were performed using the Student's $\underline{t}$-test, $p<0.05^{*} ; p<0.01^{* *}$. Figure $3 \mathrm{C}$ shows the results from immunohistochemical staining against PCNA protein in uterine epithelial cells. The percentage of PCNA-positive cells is presented as mean \pm SD. Statistical analyse was performed using the Mann-Whitney-U-test, $p<0.01 * *$; $p<0.001^{* * *}$.

Figure 4. Gene expression profiles of relevant steroid receptor genes in the uterus of differentially treated ArKO mice are analyzed upon two administration routes, per os and subcutaneous. 
Relative gene expression levels of (A) ESR1, (B) ESR2 as well as (C) $\underline{\text { EGR }}$ are normalized against the CO group (black horizontal line). Data are presented as mean \pm SD. Statistical analyses were performed using the Student's $\underline{t}$-test, $p<0.05$ *; $p<0.01^{* *}$.

Figure 5. Gene expression profiles of estrogen-response marker genes in the uterus of differentially treated ArKO mice are analyzed upon two administration routes, per os and subcutaneous.

Relative gene expression levels of $(A) \underline{L T F}$ and $(B) \underline{C 3}$ are normalized against the CO group (black horizontal line). Data are presented as mean \pm SD. Statistical analyses were performed using the Student's $\underline{t}$-test, $p<0.05^{*} ; p<0.01^{* *}$.

Figure 6. Gene expression profile of estrogen receptor $\beta$ (ESR2) gene in the ovary of differentially treated ArKO mice is analyzed upon two administration routes, per os and subcutaneous.

Relative gene expression levels are normalized against the CO group (black horizontal line). Data are presented as mean \pm SD. Statistical analyses were performed using the Student's $\underline{t}$-test $\left(p<0.05^{*}\right)$.

Figure 7. Gene expression profiles of a proliferation-associated gene (PCNA;A$)$ and an ovarian specific differentiation marker gene (LHR; $B$ ) in the ovary of differentially treated ArKO mice are analyzed upon two administration routes, per os and subcutaneous.

Data is normalized against the $\mathrm{CO}$ group (black horizontal line) and presented as mean \pm SD. Statistical analyses were performed using the Student's $\underline{t}$-test, $p<0.05$ *

Figure 8. Gene expression profiles of estrogen-responsive nuclear factors in the ovary of differentially treated ArKO mice are analyzed upon two administration routes, per os and subcutaneous.

Relative gene expression levels of (A) SF-1 and (B) LRH-1 are normalized against the CO group (black horizontal line). Data are presented as mean \pm SD. Statistical analyses were performed using the Student's $\underline{t}$-test $\left(p<0.05^{*}\right.$ and $\left.p<0.01^{* *}\right)$. 
Figure 1

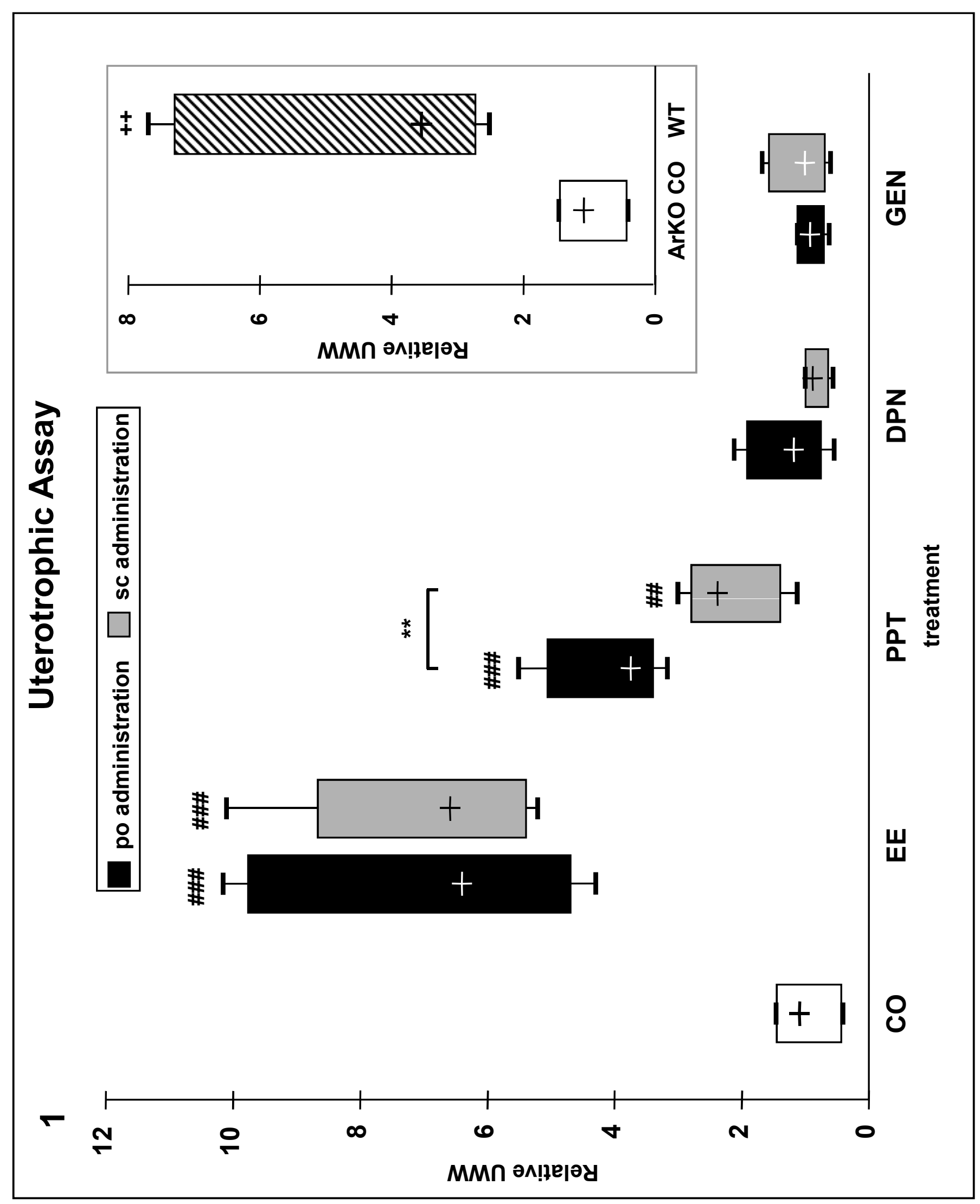


Figure 2
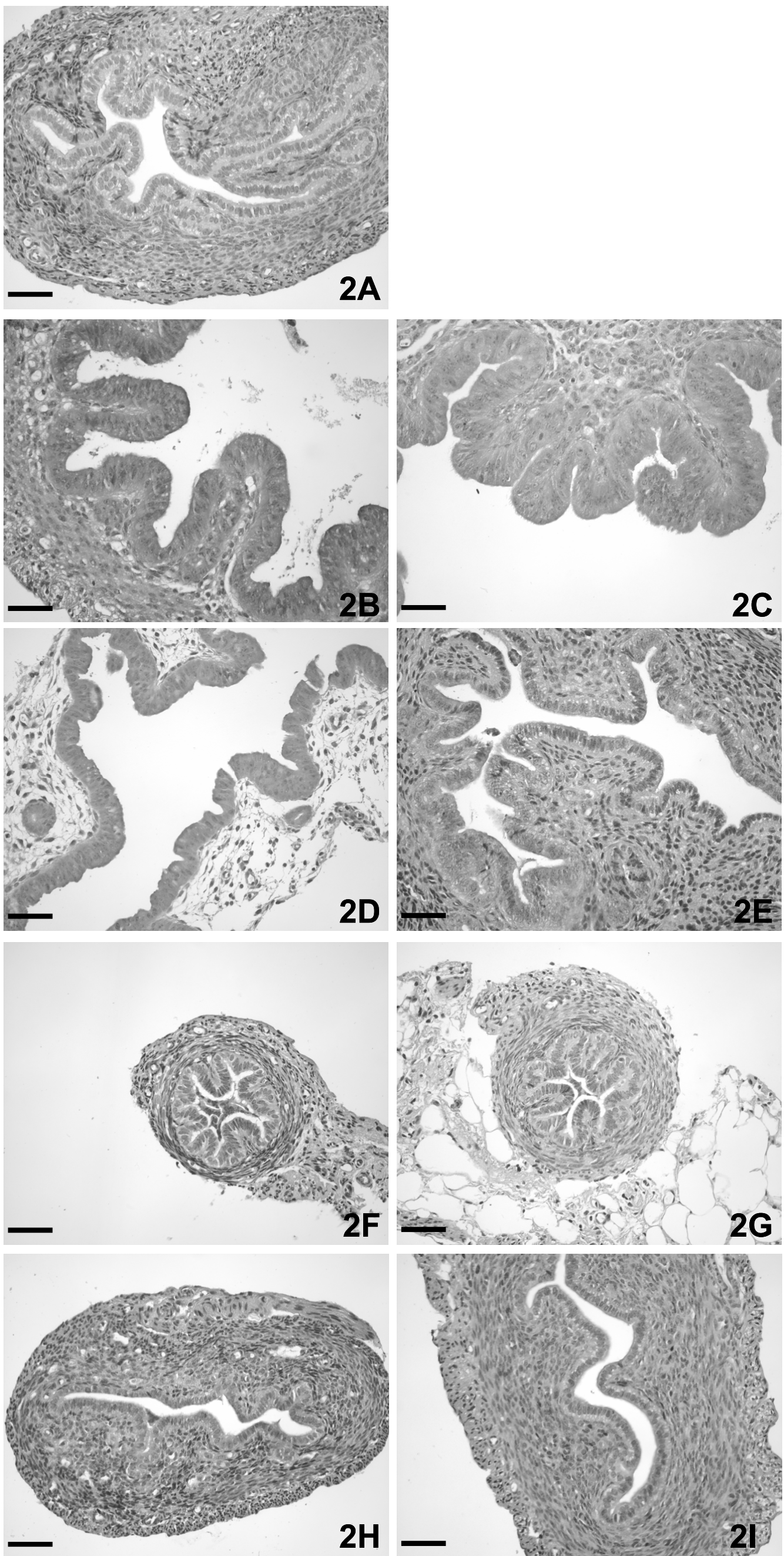
3A PCNA gene expression in the uterus

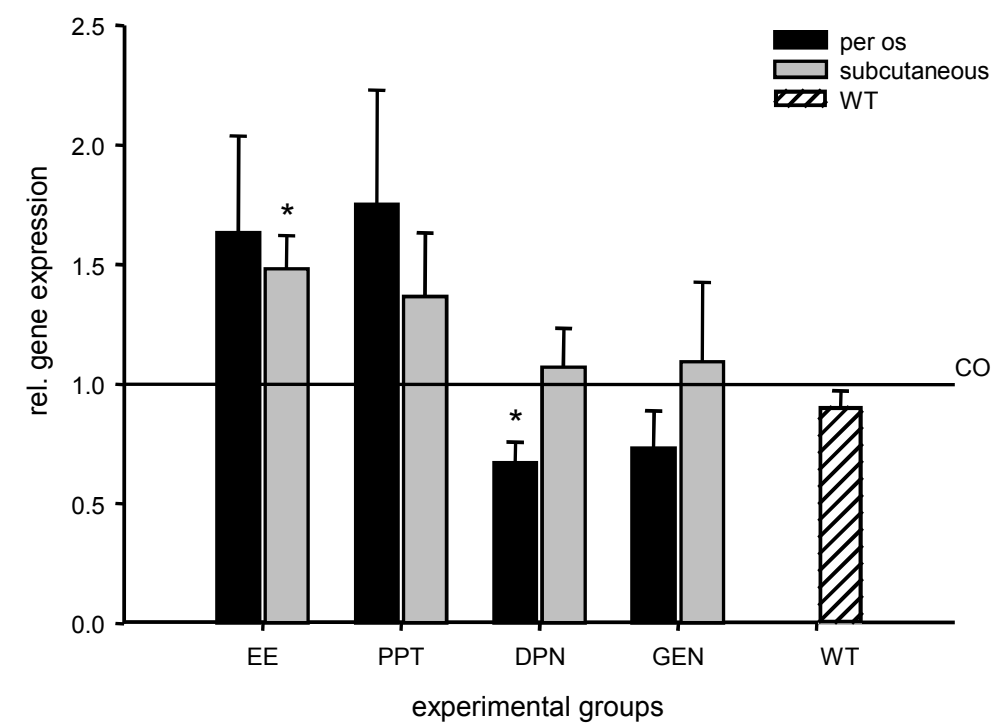

\section{B MKI67 gene expression in the uterus}
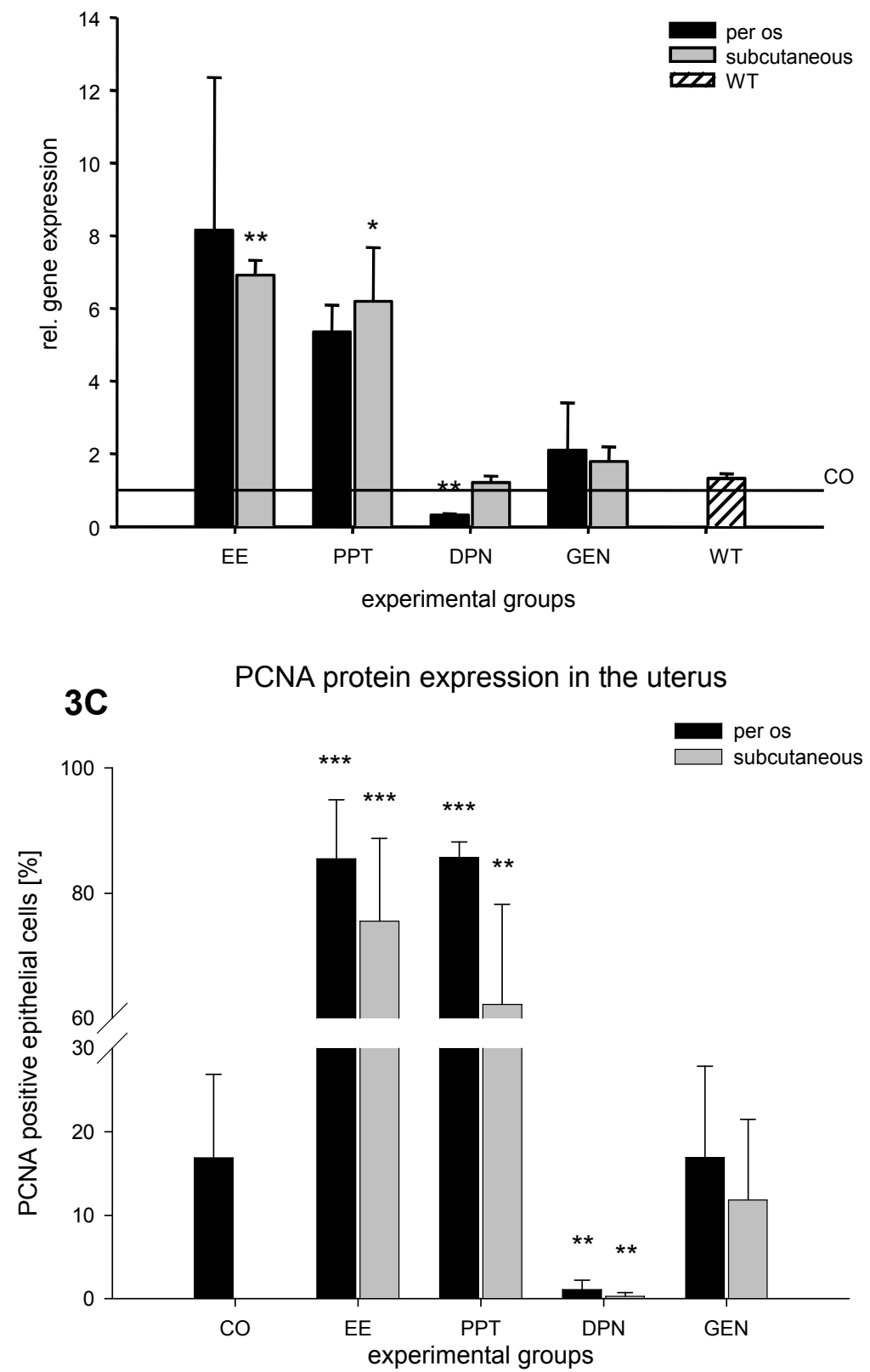
ACCEPTED MANUSCRIPT

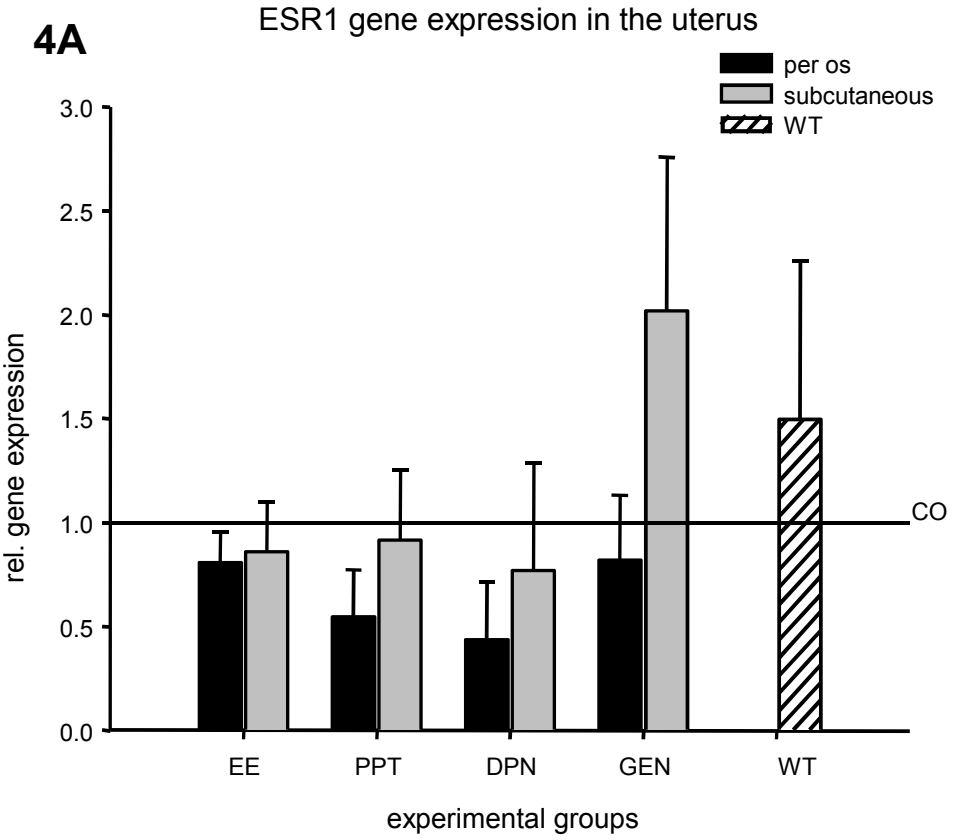

4B ESR2 gene expression in the uterus

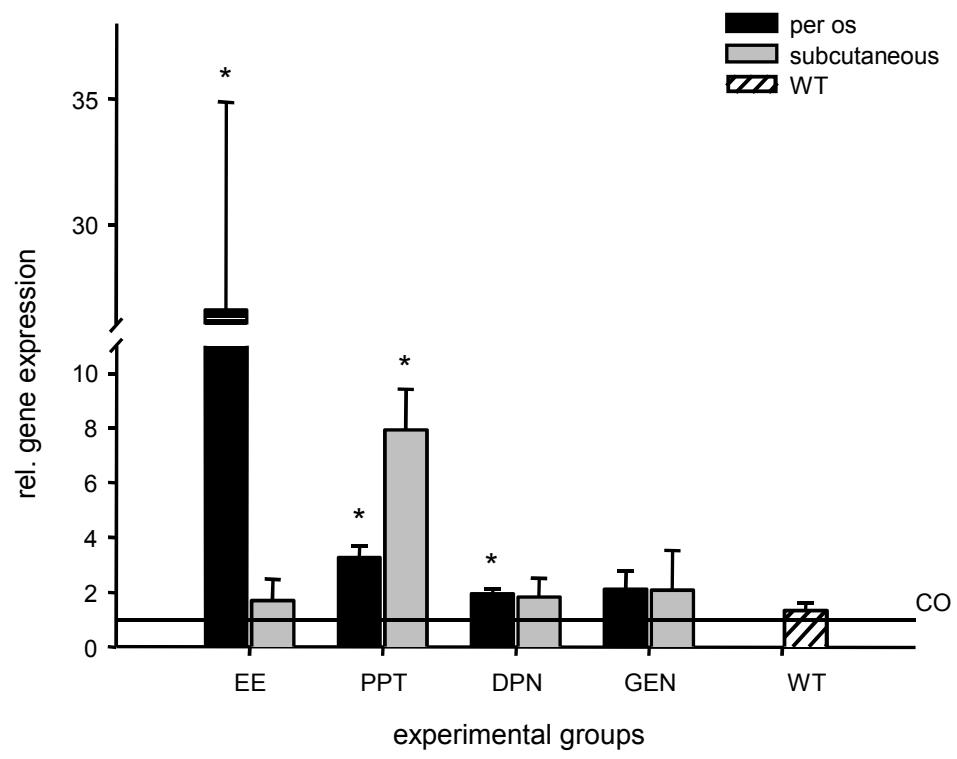

4C PGR gene expression in the uterus

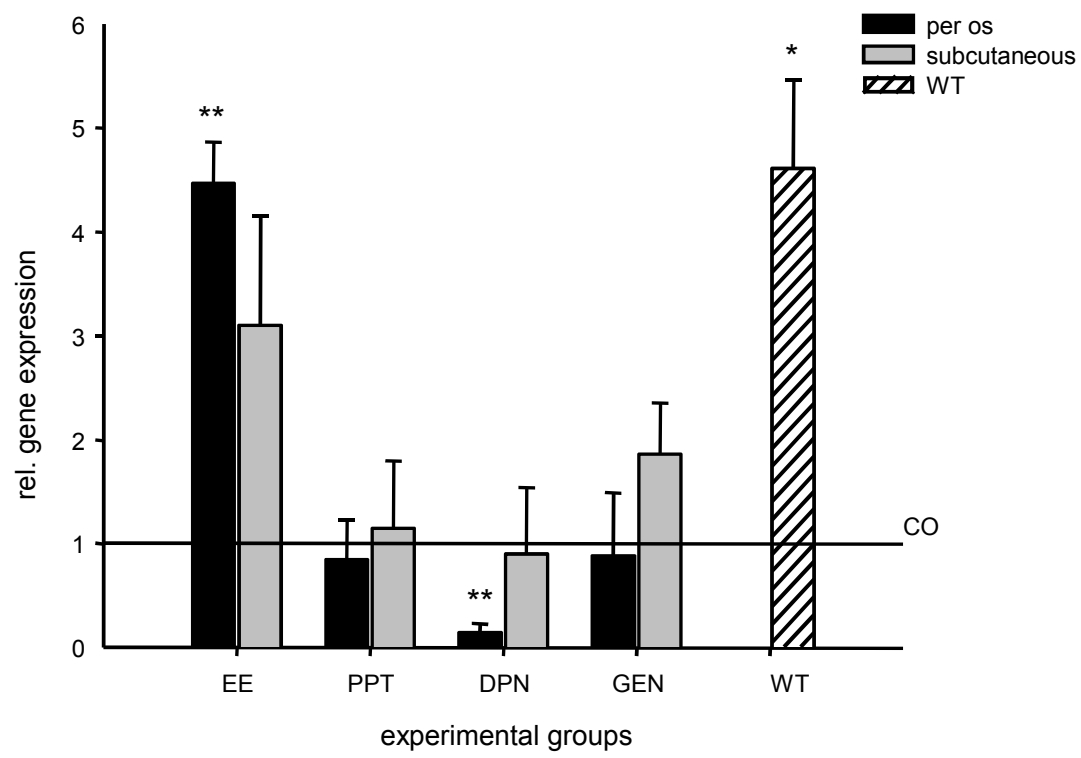

. ny _ _ 39 


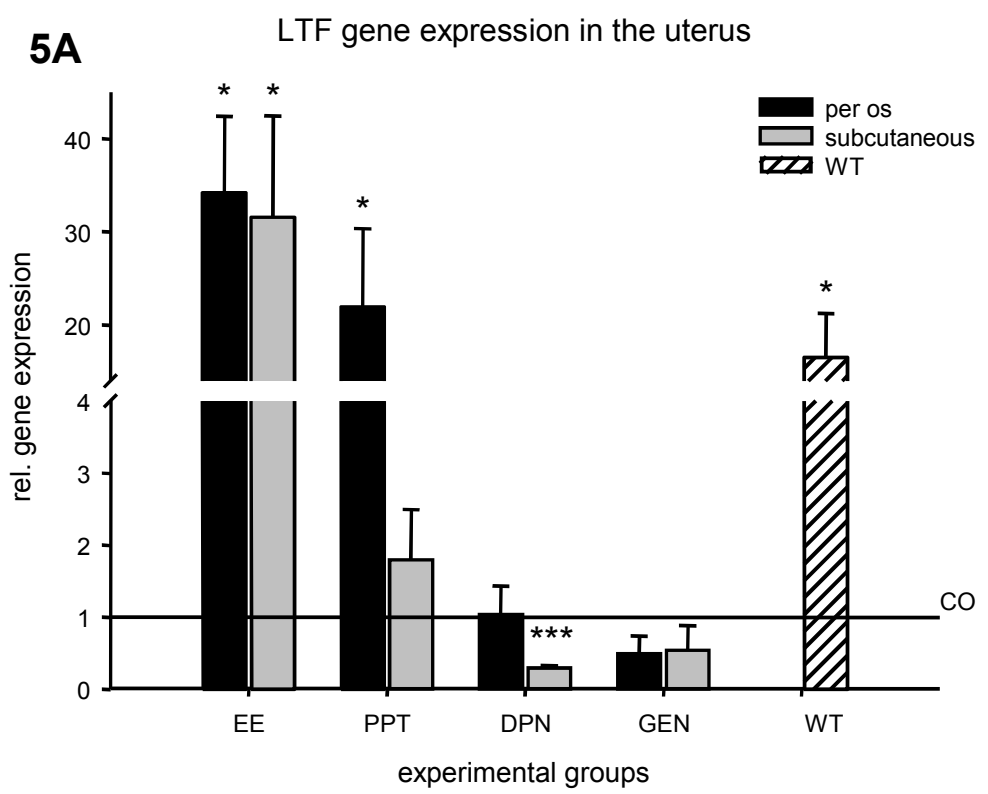

\section{B $\quad$ C3 gene expression in the uterus}

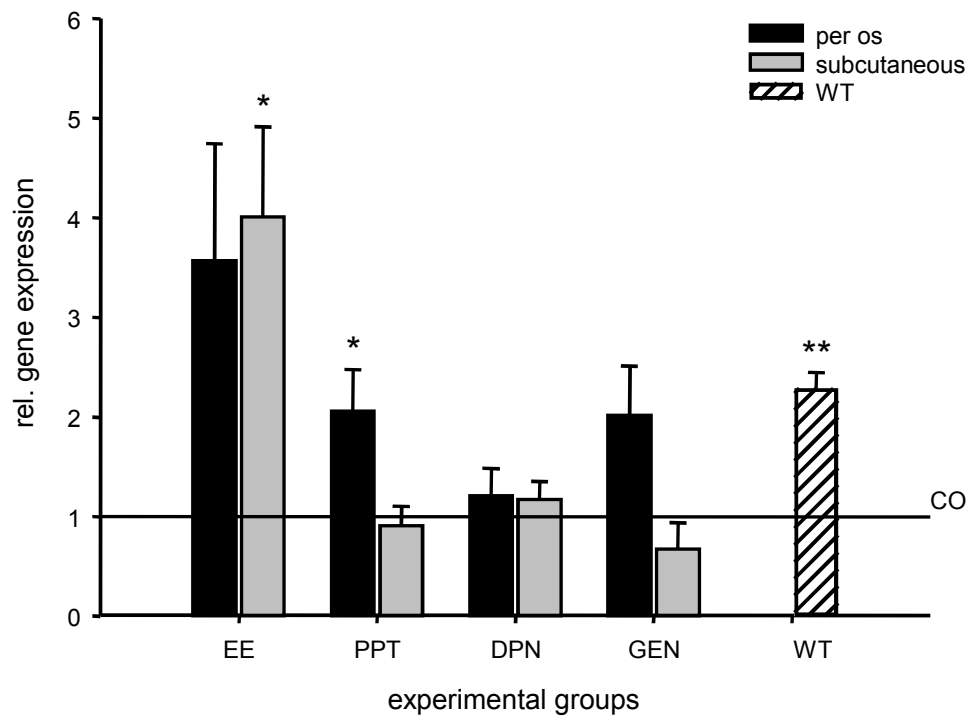




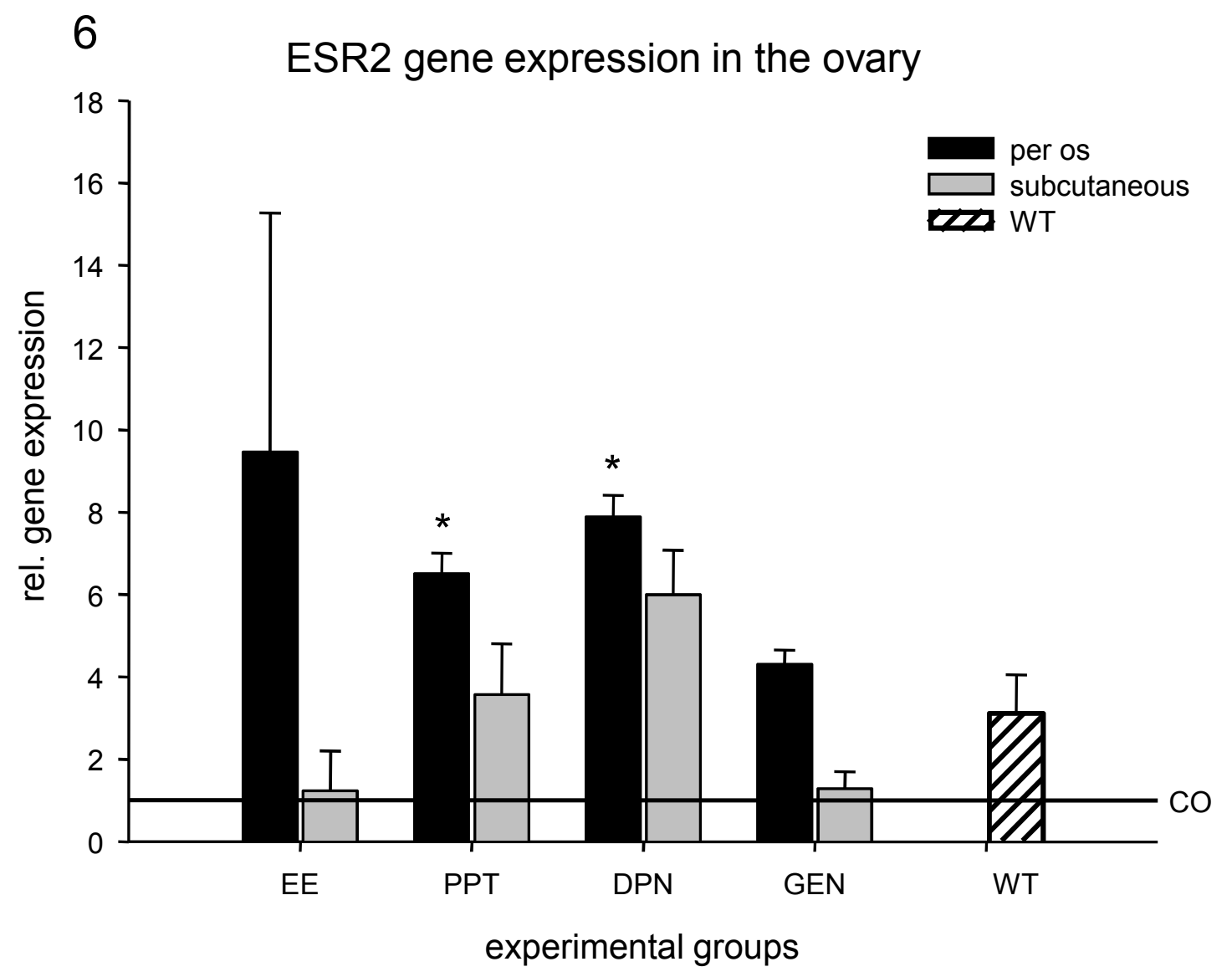



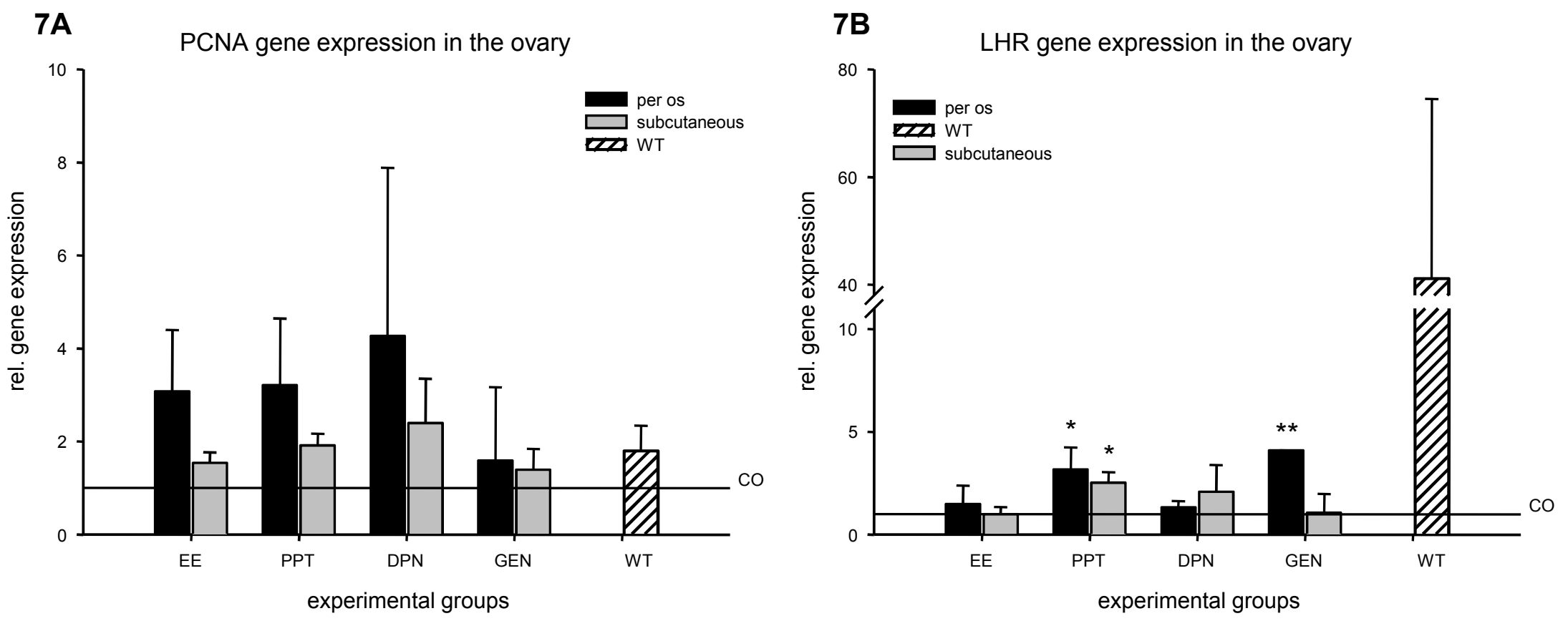

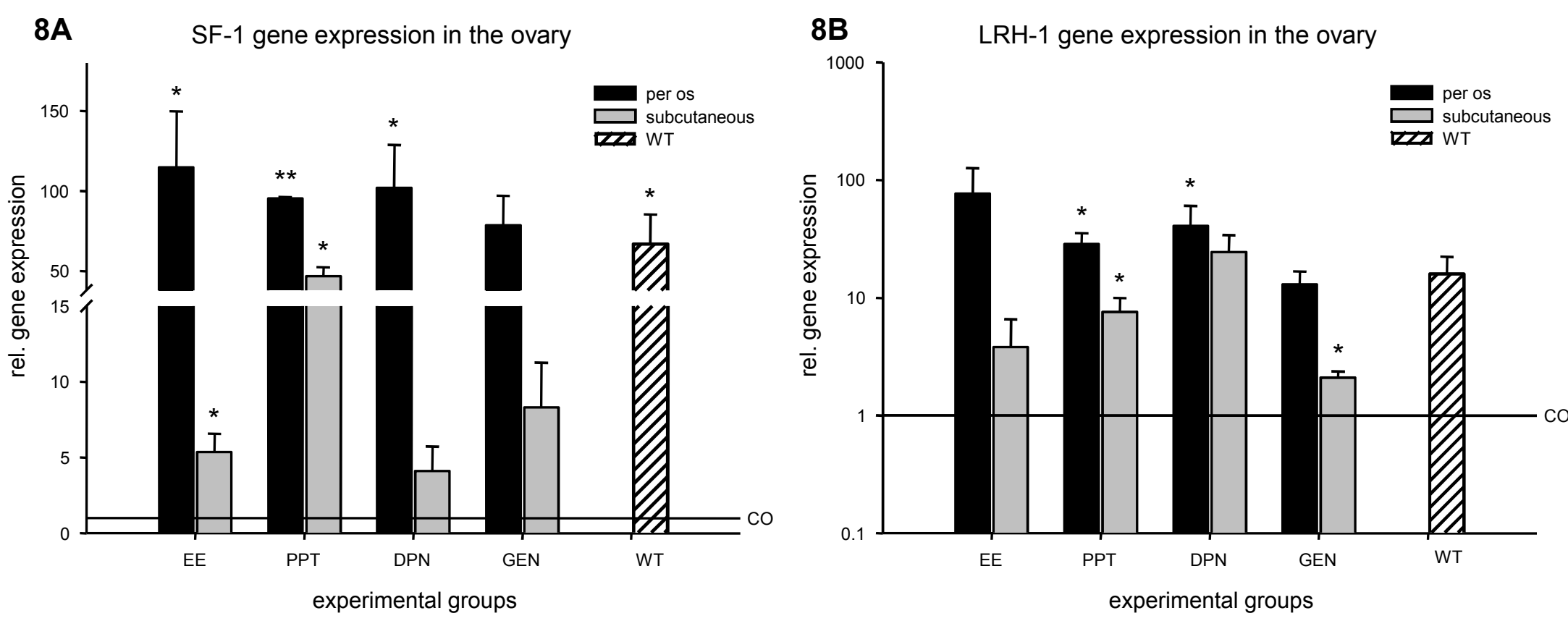